\title{
THE TWO-STAGE AEGEAN EXTENSION, FROM LOCALIZED TO DISTRIBUTED, A RESULT OF SLAB ROLLBACK ACCELERATION
}

\begin{tabular}{|r|l|}
\hline Journal: & Canadian Journal of Earth Sciences \\
\hline Manuscript ID & cjes-2015-0203.R1 \\
\hline Manuscript Type: & Article \\
\hline Date Submitted by the Author: & $17-J a n-2016$ \\
\hline Complete List of Authors: & $\begin{array}{l}\text { Brun, Jean-Pierre; University Rennes 1, Géosciences Rennes } \\
\text { Faccenna, Claudio; Università Roma Tre, Laboratory of Experimental } \\
\text { Tectonics } \\
\text { Gueydan, Frédéric; Université de Montpellier, Géosciences Montpellier } \\
\text { Sokoutis, Dimitrios; Utrecht University, Department of Earth Sciences; } \\
\text { University of Oslo, Department of Geosciences } \\
\text { Philippon, Mélody; Université des Antilles, Géosciences Montpellier } \\
\text { Kydonakis, Konstantinos; Université Rennes 1, Géosciences Rennes } \\
\text { Gorini, Christian; UPMC Université Paris 06, ISTeP }\end{array}$ \\
\hline Keyword: & $\begin{array}{l}\text { Hellenic subduction, slab rollback, trench retreat, Aegean back-arc } \\
\text { extension }\end{array}$ \\
\hline
\end{tabular}

\section{SCHOLARONE}

Manuscripts 
1 THE TWO-STAGE AEGEAN EXTENSION, FROM LOCALIZED TO 2 DISTRIBUTED, A RESULT OF SLAB ROLLBACK ACCELERATION

3 Jean-Pierre Brun, Claudio Faccenna, Frédéric Gueydan, Dimitrios Sokoutis, Mélody

4 Philippon, Konstantinos Kydonakis and Christian Gorini.

6 J.-P. Brun. Université Rennes 1, Géosciences Rennes,UMR 6118 CNRS, bat. 15 - Campus 7 de Beaulieu, 263 Av du général Leclerc, BP 74205, 35042, Rennes Cedex, France. Jean$8 \quad$ Pierre.Brun@univ-rennes1.fr

9 C. Faccenna. LET, Laboratory of Experimental Tectonics, Università Roma Tre, Rome, 10 Italy. claudio.faccenna@uniroma3.it

11 F. Gueydan. Université de Montpellier. Géosciences Montpellier, UMR5243, Université de 12 Montpellier, Rue Eugène Bataillon, France. frederic.gueydan@univ-montp2.fr

13 D. Sokoutis. Department of Earth Sciences, Faculty of Geosciences, Utrecht University, 14 Budapestlaan 4, PO Box 80021, 3508 Utrecht, The Netherlands and Department of 15 Geosciences, University of Oslo, PO Box 1047, Blindern, N-0316 Oslo, Norway. $16 \quad \underline{\text { D.Sokoutis@,uu.nl }}$

17 M. Philippon. Université des Antilles, Géosciences Montpellier, UMR 5243, Campus de 18 Fouillole, 97159, Pointe à Pitre, France. Melodie.Philippon@gm.univ-montp2.fr

19 K. Kydonakis. Université Rennes 1, Géosciences Rennes,UMR 6118 CNRS, bat. 15 20 Campus de Beaulieu, 263 Av du général Leclerc, BP 74205, 35042, Rennes Cedex, France.

21 konstantinos.kydonakis@univ-rennes1.fr

22 C. Gorini. Sorbonne Universités, UPMC Univ Paris 06, UMR 7193, ISTeP, F-75005, Paris, 23 France. christian.gorini@upmc.fr 
26 Abstract: Back-arc extension in the Aegean, which was driven by slab rollback since $45 \mathrm{Ma}$,

27 is described here for the first time in two stages. From Middle Eocene to Middle Miocene,

28 deformation was localized leading to i) the exhumation of high-pressure metamorphic rocks

29 to crustal depths, ii) the exhumation of high-temperature metamorphic rocks in core 30 complexes and iii) the deposition of sedimentary basins. Since Middle Miocene, extension

31 distributed over the whole Aegean domain controlled the deposition of onshore and offshore

32 Neogene sedimentary basins. We reconstructed this two-stage evolution in 3D and four steps

33 at Aegean scale by using available ages of metamorphic and sedimentary processes, geometry

34 and kinematics of ductile deformation, paleomagnetic data and available tomographic models.

35 The restoration model shows that the rate of trench retreat was around $0.6 \mathrm{~cm} / \mathrm{y}$ during the 36 first $30 \mathrm{My}$ and then accelerated up to $3.2 \mathrm{~cm} / \mathrm{y}$ during the last $15 \mathrm{My}$. The sharp transition 37 observed in the mode of extension, localized versus distributed, in Middle Miocene correlates 38 with the acceleration of trench retreat and is likely a consequence of the Hellenic slab tearing 39 documented by mantle tomography. The development of large dextral NE-SW strike-slip 40 faults, since Middle Miocene, is illustrated by the $450 \mathrm{Km}$-long fault zone, offshore from 41 Myrthes to Ikaria and onshore from Izmir to Balikeshir, in western Anatolia. Therefore, the 42 interaction between the Hellenic trench retreat and the westward displacement of Anatolia 43 started in Middle Miocene, almost 10 Ma before the propagation of the North Anatolian Fault 44 in the North Aegean.

45 Keywords: Hellenic subduction, slab rollback, trench retreat, Aegean back-arc extension 46 
47 Résumé: L'extension égéenne, mue par le recul de la subduction Hellénique, est un processus 48 qui, depuis $45 \mathrm{Ma}$, montre une évolution en deux stades. De l'Eocène moyen au Miocène 49 moyen, la déformation localisée est matérialisée par i) l'exhumation de roches 50 métamorphiques de haute pression, ii) l'exhumation de roches de haute température dans des 51 “core complexes" et iii) le dépôt de bassins sédimentaires Paléogènes. Depuis le Miocène 52 moyen, l'extension est distribuée dans tout le domaine égéen contrôle le développement de 53 bassins sédimentaires Néogènes. Cette évolution en deux stades à l'échelle de l'ensemble du 54 domaine égéen est reconstruite en utilisant les âges des processus métamorphiques et 55 sédimentaires, la cinématique de la déformation ductile, les données paléomagnétiques 56 existantes et les modèles tomographiques les plus récents. Le modèle de restauration montre 57 que la vitesse de recul de la subduction, de 0,6 cm/an pendant les premiers $30 \mathrm{Ma}$, s'est 58 accélérée au Miocène moyen pour atteindre $3.2 \mathrm{~cm} / \mathrm{an}$ au cours des derniers $15 \mathrm{Ma}$. La 59 transition localisée-distribuée de l'extension au Miocène moyen, corrélée avec l'accélération $60 \mathrm{du}$ recul de la fosse, est probablement une conséquence de la déchirure du panneau de 61 lithosphère subductée. Le développement de grands décrochements dextres orientés NE-SW 62 pendant le deuxième stade d'extension indique que l'interaction entre le recul de la 63 subduction Hellénique et le déplacement vers l'Ouest de l'Anatolie a débuté au Miocène 64 moyen, 10 Ma avant l'arrivée de la Faille Nord Anatolienne dans le Nord de l'Egée. 


\section{Introduction}

The Aegean Tertiary tectonic history corresponds to back-arc extension driven by slab rollback (Royden 1993; Jolivet and Faccenna 2000; Faccenna et al. 2003, 2014, Brun and Faccenna 2008). Extension started around 45 Ma ago (Brun and Sokoutis 2010) and accommodated up to $600 \mathrm{~km}$ of trench retreat (Jolivet and Brun, 2010; Jolivet et al. 2013).

Extension followed the closure of Vardar and Pindos oceanic domains in Cretaceous-Eocene (Dercourt et al. 1993; Channell and Kozur 1997; Robertson 2004) that led to the stacking of three continental blocks: Rhodopia, Pelagonia and Adria, from top to base (Fig. 1). Tomographic models of the underlying mantle image a single slab (Wortel and Spakman 2000; Piromallo and Morelli 2003; Widiyantoro et al. 2004) indicating that the convergence of continental blocks, now separated by two suture zones, has been accommodated by a single subduction (Faccenna et al. 2003).

The first plate kinematic models of eastern Mediterranean (McKenzie 1972, 1978; Le Pichon and Angelier 1981) and the present-day displacement field from satellite geodesy (McClusky et al. 2000; Hollenstein et al. 2008; Müller et al. 2013) show that the active pattern of extension combines the effects of the southwestward retreat of the Hellenic trench and the westward displacement of Anatolia along the North Anatolian Fault (NAF). The geological record shows that this interaction between two strongly oblique components of boundary displacement started during Middle Miocene (Dewey and Şengör 1979; Şengör et al. 2005; Philippon et al. 2014), around 10 My before the NAF reached the Aegean (Armijo et al. 1999; Hubert-Ferrari et al. 2003; Şengör et al. 2005). On the other hand, the coeval extensional exhumation of high-pressure metamorphic rocks in the Cyclades and hightemperature metamorphic rocks in the Rhodope (Brun and Sokoutis 2007; Brun and Faccenna 2008) started in Middle Eocene (see review of data in Jolivet and Brun 2010 and Philippon et al. 2012). This brief summary of the extension history during a large part of the Tertiary 
91 indicates a process that has not been continuous, neither in time nor in space. This is

92 illustrated by a striking difference in the distribution of Paleogene and Neogene sedimentary

93 basins at Aegean scale (Fig. 2) suggesting that a major change in the dynamics of extension 94 occurred in Middle Miocene, more 30 My after its onset.

95 The present article describes back-arc extension in the Aegean, in two main stages 96 localized from Middle Eocene to Middle Miocene and distributed since Middle Miocene, and 97 their most significant large-scale features in terms of sedimentation, deformation and 98 metamorphism. Then, it presents a 3D restoration of the extensional displacements in four steps since Middle Eocene. It is shown that the transition in the mode of extension from localized (core complex) to distributed (wide rift), during Middle Miocene, is coeval with an acceleration of trench retreat. Finally, it is argued that this acceleration i) likely resulted from the tearing of the Hellenic slab documented by mantle tomography and ii) was coeval with the onset of Anatolia westward displacement.

\section{Stage 1: Paleogene basins and ductile exhumation of metamorphic rocks}

The first stage of extension, from Middle Eocene to Middle Miocene is recorded in the deposition of sedimentary basins and in the exhumation of high-temperature metamorphic core complexes and high-pressure metamorphic belts.

located i) on top of the Rhodopia block (Trace Basin: Görür and Okay 1996; Siyako and

111 Huvaz 2007; Kilias et al. 2013); Vardar-Thermaikos Basin: Roussos 1994; Carras and

112 Georgala 1998) and ii) on top of Pelagonia (Mesohellenic Trough: Doutsos et al. 1994;

113 Ferrière et al. 2004) (Fig. 2a). The Thrace Basin that started subsiding in Early Eocene

114 contains sedimentary rocks from Lower-Middle Eocene to Pleistocene, reaching a thickness

115 up to $9000 \mathrm{~m}$. The sedimentary units are dominantly marine-prodelta organic-rich shales and 
116 turbidites. The transition from Eocene to Lower Oligocene outcrops in the Lemnos Island 117 (Maravelis and Zelilidis 2011). The Thrace Basin has recorded only moderate tectonic events.

118 The initial subsidence controlled the deposition of Middle-Eocene to Oligocene sediments.

119 Early Miocene sediments deposited during an event of inversion/folding are unconformably 120 sealed by Middle to Late Miocene deposits. The Mesohellenic Through (MHT) extends over $121300 \mathrm{Km}$ with a mean width of $40 \mathrm{~km}$ from Albania to Greece along a NNW-SSE trend along 122 the northern side of the Pindos suture zone (Doutsos et al. 1994; Ferrière et al. 2004). Its 123 sedimentary fill also ranges from the Late Eocene to Middle Miocene. A first megasequence 124 is composed, from base to top, of Late Eocene tectonic breccia, mass transport deposits, 125 turbidites, fluvial conglomerates and deltaic plain sediments at the transition with the 126 Oligocene. A second megasequence is characterized by Oligocene carbonates at the base. 127 This platform is rapidly drowned by a rapid subsidence with the deposition of hundred meters 128 of sands and silts organized in deltaic lobes.

The Southern Rhodope Core Complex (SRCC) (Fig. 3) (Dinter and Royden 1993;

130 Sokoutis et al. 1993; Brun and Sokoutis 2007), located to the North of the Vardar suture zone, 131 started to develop in Middle Eocene, around $45 \mathrm{Ma}$, and was controlled by the SW dipping 132 Kerdylion detachment. The detachment hanging-wall is made of the metamorphic units of the 133 Chalkidiki peninsula whose tectonic-metamorphic evolution is dominantly Mesozoic and 134 which correspond to the western and most external part of Rhodopia (Kydonakis et al. $2015 \mathrm{~b}$ 135 and in press). The detachment footwall (i.e. the core) consists mostly a Hercynian basement 136 made of orthogneisses, paragneisses and marbles dated as Permian at their base (i.e. a 137 Pelagonian-type assemblage) affected by a high-temperature metamorphism that at many 138 places reached partial melting in Barrovian-type metamorphic conditions (Dimitriadis 1989). 139 To the North, the Nestos Thrust (Burg 2011; Nagel et al. 2011) separates these core units 140 from the northern part of Rhodopia. Therefore, at regional-scale, the SRCC corresponds to a 
141 tectonic window in which Pelagonia is exposed. Consequently, we interpret the Nestos thrust 142 that separates northern Rhodopia from Pelagonia as the Vardar Suture Zone. Prior to the 50 143 Ma migmatisation (Wawrzenitz and Krohe 1998), the Pelagonian core units were sheared and 144 duplicated by SW directed thrusting (Brun and Sokoutis 2007). From Middle Eocene to 145 Middle Miocene, the same units, as well as Oligocene and Lower Miocene granite intrusions 146 (Kyriakopoulos et al. 1989, 1997; Kolocotroni and Dixon 1991; Dinter et al. 1995), recorded 147 a second shearing event again toward the SW but in extension, during the exhumation of the 148 core complex (Dinter and Royden 1993; Sokoutis et al. 1993); that extensional phase was 149 primarily controlled by the SW-dipping Kerdylion Detachment (Brun and Sokoutis 2007).

150 Everywhere within the exhumed units, the gneisses are mylonitic but approaching the 151 Kerdylion Detachment they become ultramylonitic with thick cataclasites at the hanging-wall 152 contact. Paleomagnetic data (Dimitriadis et al. 1998) indicate that the core complex exhumed 153 during a $30^{\circ}$ dextral rotation of the hanging-wall (Chalkidiki Peninsula) what is in agreement 154 with the northwestward-closing triangular shape of the core complex map contours at regional 155 scale (Brun and Sokoutis 2007). Since Middle Miocene, the exhumed core units have been 156 segmented by two sets of normal faults trending NE-SW and NW-SE that controlled the 157 deposition of Neogene basins (Lalechos 1986; Snel et al. 2006, Brun and Sokoutis 2007). In 158 its largest width, to the Southeast, the bulk extensional displacement, including the brittle 159 segmentation of the core complex, reached around $120 \mathrm{~km}$. The Central Cyclades Core 160 Complex (CCCC) (Philippon et al. 2012) is located the South of the Vardar Suture Zone and 161 outcrops in the central islands of the Cyclades (Fig.3): Naxos-Paros and Mykonos-Delos162 Rhenia. This core complex developed entirely within the Adria crustal block. The core units 163 display a high-temperature metamorphism reaching partial melting that was superposed to a 164 previous stage of high-pressure metamorphism. In Paros a fast heating from $350^{\circ} \mathrm{C}$ to $700^{\circ} \mathrm{C}$ 165 occurred between 35 and $20 \mathrm{Ma}$ (Bargnesi et al. 2013). In Naxos, where the peak of high- 
166 pressure metamorphism is dated around 45-50 Ma (Duchene et al 2006; Martin et al 2006),

167 partial melting commenced prior to 20.7 Ma (Keay et al. 2001). A characteristic PTt

168 trajectory of Naxos migmatites is shown in Figure 3 (modified after Duchêne et al. 2006).

169 Core units show a stretching lineation dominantly oriented N-S with an associated top N 170 sense of shear in Naxos-Paros (Gautier et al. 1989, 1993; Urai et al. 1990; Buik 1991) and

171 NE-SW-oriented with a top NE sense of shear in Mykonos-Delos-Rhenia (Leconte et al.

172 2010) in agreement with a N-dipping but wavy detachment in Naxos-Paros and a NE-dipping

173 detachment in Mykonos-Delos-Rhenia. These differences in structural and kinematic patterns

174 are often interpreted as two separated core complexes with independent and non-connected

175 detachments (e.g. Jolivet et al. 2010; Denèle et al. 2011). Consequently, this would imply

176 distinct dynamics of development. The two groups of islands are separated by a regional-scale

177 discontinuity trending NE-SW (Gautier and Brun 1994; later called "Mid-Cyclades

178 Lineament" by Walcott and White 1998). Philippon et al. (2012) showed that the restoration

179 of post-Middle Miocene faulting using available paleomagnetic data brings the two trends of

180 stretching lineations into parallelism and the two groups of islands in geometrical continuity,

181 revealing that hidden below the scattering of islands was initially a single core complex (i.e.

182 the $\mathrm{CCCC}$ ). The restoration also showed that the Mid-Cyclades Lineament can be interpreted 183 as a dextral strike-slip fault, with an offset in the order of $50 \mathrm{~km}$, that was called by Philippon 184 et al. (2014) Myrthes-Ikaria fault (MIF in Fig. 3) as it transforms the post-Middle Miocene 185 opening of the Myrthes and Ikaria basins located at its SW and NE tips, respectively. In this 186 frame, the wavy shape of the Naxos-Paros detachment appears to result from an E-W 187 component of shortening (as already suggested by Avigad et al. 2001 at the scale of the 188 central Cyclades and by Urai et al. 1990 and Buik (1991) from the observation of outcrop189 scale folds in Naxos). 
191

192

during the closure of the Vardar and Pindos oceanic domains. Their exhumation was accommodated by extension, dominantly during "Stage 1" and partly during "Stage 2". The Cycladic Blueschist Unit (CBU) is constituted by: i) at the base, a Hercynian basement dominantly made of granite orthogneisses, ii) a sedimentary cover where alternate marbles and schist sequences whose depositional ages range from Visean to Eocene and iii) at the top, an ophiolitic mélange made of serpentine schists with Triassic to Cretaceous metagabbro and metabasalt knockers that could represent either relicts of the Pindos Ocean itself or part of the Adria subcontinental lithospheric mantle that was partially molten during the stretching and rifting stage of the Pindos ocean. The rather similar ranges of pressure peaks in the oceanictype rocks $(0.8-2.2 \mathrm{GPa})$ and in the sedimentary cover $(0.6-1.8 \mathrm{GPa})$ indicate that the basement, its sedimentary cover and the oceanic-type rocks were subducted at comparable depths. The compilation of geochronological data obtained by various methods in 10 different Cycladic islands (Fig.5 in Philippon et al. 2012) shows: i) that the ages of high-pressure metamorphism range between 58 and $40 \mathrm{Ma}$ and ii) that the blueschist-greenschist transition occurred in a narrow age range of 3 My between 35 and 32 Ma. This indicates that the CBU was exhuming in Late Eocene-Early Oligocene as a whole coherent unit, in agreement with the preservation, in many islands, of the superposition cover on basement with or without ophiolitic mélange at the top. In addition, nummulitic turbidites (Lutetian) are involved in thrust deformation and have recorded a metamorphic pressure of 1-1.2 GPa (Shaked et al. 2000; Ring et al. 2007; Rosenbaum and Ring 2007). Together with the Middle Eocene age of the youngest pressure peaks, this shows that subduction-related thrusting was active until Middle Eocene. As the blueschist-greenschist transition occurred between 35 and $32 \mathrm{Ma}$, the delay between the end of subduction and the onset of exhumation has been short, more likely less than 5 My. The PTt trajectory of Tinos blueschists (Fig. 4) (Parra et al 2002; Jolivet and 
215 Brun 2010) shows that an isobaric heating occurred during exhumation between 37 and 33

216 Ma. As Tinos is close to the CCCC (Fig. 3) this is more likely related with the heating

217 observed in Paros in the same range of ages (Bargnesi et al 2013). Three main events of

218 pervasive ductile deformation that can be characterized at regional scale by stretching

219 lineations and associated senses of shear characterize the CBU (Philippon et al. 2012): (1)

220 prior to at least $40 \mathrm{Ma}$, a subduction-related layer-parallel shear top to SW and top to S to the

221 NW and to the SE of the MIF, respectively (Black arrows in Fig. 4), (2) from 40 to 20 Ma, an

222 exhumation-related layer-parallel shear of weak to moderate intensity, prior to the onset of the

223 North Cycladic detachment, top to N or NE to the NW and to the SE of the MIF, respectively

224 (White arrows in Fig. 4), (3) from 20 to $13 \mathrm{Ma}$ and observed in the islands adjacent to the

225 North Cycladic detachment, a top to NE shear in general of strong intensity affects the

226 blueschists as well as high temperature rocks of the CCCC (Red arrows in Fig. 3). The high-

227 pressure metamorphic unit of Peloponnese and Crete is characterized by an exhumation

228 history younger than the CBU one (Fig. 4). It was still undergoing burial when the CBU was

229 already exhuming. Exhumation occurred in Late Oligocene-Lower Miocene without

230 significant heating during exhumation. In this most external part of Adria, high-pressure low-

231 temperature (HP-LT) metamorphism is only recorded in the " Phyllite-Quartzite Nappe “

232 (PQN) (see comprehensive review by Jolivet et al. $2010 b$ and references therein). The HP-LT

233 PQN is sandwiched between two thick thrust units composed of Triassic to Eocene

234 formations, namely the Gavrovo-Tripolitza Nappe (GTN) on top and the "Plattenkalk Nappe"

235 below. As pointed out by Stöckhert et al. (1999), the average resistance of the PQN was much

236 smaller than the overlying and underlying units and consequently localized a large part of the

237 deformation during burial and exhumation. From a mechanical point of view, the PQN is

238 therefore a décollement (i.e. dominated by layer-parallel shear) and relating its deformation to

239 a detachment (shear zone cutting down section), as done in most published works, is rather 
240 misleading. This is confirmed by the presence of the GTN over the whole Peloponnese-Crete 241 region and the common outcropping of the PQN in windows of the GTN. A detachment, 242 significant at regional-scale, should have exposed the PQN over a large domain without the 243 GTN on top. In Peloponnese, stretching lineations related to thrusting and exhumation trend 244 EW but with a sense of shear top to W for thrusting (black arrows in Fig. 4) and top to E for 245 exhumation (white arrows in Fig. 4). In Crete, stretching lineations related to exhumation 246 trend NS (white arrows in Fig. 4). The orthogonality of stretching directions related to 247 exhumation and the convergence of associated senses of shear imply that Peloponnese and 248 Crete have undergone a nearly $90^{\circ}$ relative rotation after the end of ductile deformation.

249 In summary, the exhumation of core complexes (high-temperature metamorphism) and 250 blueschists (high-pressure metamorphism) results from significantly different mechanisms of 251 development, primarily controlled by temperature-dependent rheology of the crustal units. 252 Therefore, their location in the Aegean, as well as their relative timing of development, has an 253 important mechanical significance:

254 - The SRCC started to develop in Middle-Late Eocene in North Aegean when the CBU 255 started to exhume in central Aegean,

256 - The CCCC developed in central Aegean in lower Miocene almost synchronous with 257 the onset of HP-LT PQN exhumation in Peloponnese and Crete.

258 - The sense of shear and detachment dip in core complexes and sense of shear in high259 pressure rocks, is top to SW in North Aegean (SRCC), to NE in central Aegean (CBU and CCCC) and to E and N in South Aegean (HP-LT PQN).

261 - The part of exhumation synchronous with ductile deformation ended in Middle 262 Miocene in all types of metamorphic rocks, either high-temperature (SRCC and 263 CCCC) or high pressure (CBU and HP-LT PQN) and whatever age of onset. 
Remark: The high-pressure to ultrahigh-pressure metamorphic units of the Southwest

266 Rhodope (Kydonakis et al. 2015b) and the North Rhodope (Mposkos and Kostopoulos 2001,

267 Liati 2005) developed during the Cretaceous, and were exhumed before Eocene, prior to the 268 onset of back-arc extension in the Aegean (Kydonakis et al. 2014, Kydonakis et al. 2015b and 2692015 c) controlled by the Hellenic slab rollback. Therefore, they are outside the scope of the 270 present paper.

271

272 Stage 2: Neogene basins, segmentation of metamorphic units and dextral transtensional 273 faulting

274 The Neogene basins (Fig. 2b) whose deposition started in Middle Miocene constitute 275 one of the most striking geological features of the Aegean domain, both onshore and offshore. 276 They emplaced on all types of rock units (Paleogene basins, high-temperature or high277 pressure metamorphic units, plutonic massives and volcanic buildups) of Rhodopia, Pelagonia 278 and Adria and over around $1000 \mathrm{~km}$ from Crete to Rhodope. The earlier deposits are 279 Langhian-Serravalian in some basins of the North Aegean (e.g. Prinos; Chiotis 1984; Beniest 280 et al. 2015). Where structural data are available, field measurements or seismics, tectonic 281 setting of most basins is extensional or transtensional (e.g. Mercier et al. 1987, 1989; Lyberis 282 1984; Mascle and Martin 1990; Koukouvelas and Aydin 2002; Sakellariou et al. 2013). In the 283 islands of the North Aegean and Eastern Cyclades where it can be observed, the Late Miocene 284 corresponds to continental lacustrine and alluvial series (Lesbos and Chios: Jones 1971; 285 Samos: Weidmann et al. 1984, Beniest et al 2015). In Samos, the sediments are dated from 10 286 to $6 \mathrm{Ma}$ by the intercalation of volcanic rocks (Weidmann et al. 1984) and mammals (Koufos 287 et al. 2009), with a very rapid subsidence until $8 \mathrm{Ma}$ (Deschamps et al. 2013). During the 288 Messinian, a sea of brackish-water character developed between the Paratethys to the North 289 and the Mediterranean to the South. At that time the Aegean Sea was principally fed by 
290 surrounding rivers and/or by Paratethyan waters. The sedimentary sequence deposited is 291 principally composed of limestone containing brackish-water Paratethyan fauna, with some 292 intercalations with Mediterranean species indicating the re-establishment of a non-permanent 293 Atlantic-Mediterranean connection and, thus, replenishment of marine waters (Bache et al 294 2011). The Pliocene-Quaternary is characterized by a definitive restoration of the marine 295 conditions in the Aegean.

Low-temperature thermochronology ages, obtained by various methods (apatite and 297 zircon fission-track and $\mathrm{U}-\mathrm{Th} / \mathrm{He}$ on apatite and zircon) in high-temperature and high298 pressure metamorphic units, which were exhumed during the first stage of extension, are 299 dominantly Serravalian-Tortonian, over the whole Aegean (Fig. 5). This indicates that 300 metamorphic rocks of the SRCC, the CBU-CCCC and Peloponnese-Crete, whose onsets of exhumation were different, were reaching the surface in Middle-Late Miocene. In the core complexes and high-pressure metamorphic rocks of the Aegean these ages of exhumation are commonly considered to provide an age for the end of normal sense displacement along a 304 detachment. But the synchronism, at the whole Aegean scale, between the first sediment 305 deposition in Neogene basins and the final stages of metamorphic rock exhumation put this 306 type of interpretation in question, as most Neogene basins cannot be put in relation with any 307 major crustal-scale detachment. In the Rhodope, Serravalian-Tortonian sediments are 308 deposited on the hanging-wall of normal faults that cut through the metamorphic rocks of the 309 SRCC (Brun and Sokoutis 2007). Simultaneously, the footwall of these faults was uplifted, 310 reaching altitudes up to $1000-2000 \mathrm{~m}$. These normal faults trend either NW-SE, almost 311 parallel to the core complex detachment, or NE-SW, perpendicular to the detachment. 312 Whatever the fault trend, rocks from their footwall give the same range of thermochronology 313 ages (Fig. 5), showing that these ages are not related to the functioning of the core complex 314 detachment but to a superposed event of faulting that segmented the core complex. The 
315 Cyclades archipelago resulted from the segmentation by normal faults within the CBU and 316 the CCCC (see restoration in Philippon et al. 2012). As quoted in section 2.2, the Myrthes317 Ikaria fault (MIF), which trends NE-SW, separated the Cyclades in two main domains (Fig. 6) 318 (Philippon et al. 2014). To the NW of the MIF, the islands correspond to the residual reliefs 319 remaining above the sea level from the uplift of normal fault footwalls. To the SE border of 320 MIF, the high altitude of Paros-Naxos (up to $600 \mathrm{~m}$ ) is likely related to upright folding of the 321 core complex under a component of EW shortening (Avigad et al. 2001; Philippon et al. 322 2012). Two reasons could explain the lack of Middle-Late Miocene basin remnants in the 323 Cyclades: i) the islands represent the upper part of normal fault footwalls and ii) erosion could 324 have removed possibly inverted basins. However, Samos to the East of the Cyclades shows 325 Tortonian sediments that were deposited in transtension and locally reworked in compression 326 around $9 \mathrm{Ma}$ (Ring and Ochrusk 2007). The statistical distribution of thermochronology ages 327 (Fig. 5) obtained in 10 Cyclades islands, in either the CBU or the CCCC, is Middle-Late 328 Miocene with a strong peak in Tortonian (See data compilation in Fig.12 of Philippon et al. 329 2012).

330 Dextral strike-slip faulting is an important part of the active Aegean fault pattern, in 331 particular in the North Aegean, recognized through dynamic analysis of fault systems 332 (Mercier et al 1987, 1989; Lyberis 1984; Lyberis and Sauvage 1985), structural mapping 333 (Armijo et al. 1999; Papanikolaou et al. 2006), seismicity and earthquake focal mechanisms 334 (Hatzfeld 1999; Taymaz et al. 1991; Goldworthy et al. 2002). Among these faults, the 1200 335 km-long North Anatolian Fault (NAF), which today accommodates the westward 336 displacement of Anatolia, focus considerable and justified attention related to seismic risk 337 from both societal consequences and scientific points of view. In the frame of this paper, our 338 concern is the role, in time and space, that the NAF played in the Aegean dynamic evolution 339 since Middle Miocene, called here stage 2 extension. Thirty-six years ago, Dewey and Şengör 
340 (1979) recognized that the NAF had been preceded by a larger zone of displacement initiated 341 in Late Miocene, connected to the Bitlis suture in eastern Anatolia, as the "Proto-Anatolian 342 Transform". More recently, Şengör et al. (2005) on the basis of quantitative arguments, 343 derived from the study of Neogene basins in North Anatolia, showed that the NAF resulted 344 from strain localization within the $100 \mathrm{~km}$ wide North Anatolian Shear Zone (NASZ). 345 Localization in Western Turkey (Dardanelle strait) is estimated around $5 \mathrm{Ma}$ (Armijo et al. 346 1999). To the West of the Dardanelle Strait, the NAF takes a NE-SW direction and joins the 347 SSW-NNE-trending North Aegean Through (NAT) (Lyberis et al. 1984; Koukouvelas and 348 Aydin 2002) that is the major bathymetric depression of North Aegean (Papanikolaou et al. 349 2002). The NAT likely originated in Paleogene as a transtensional structure to laterally 350 accommodate the dextral rotation of the Chalkidiki block with reference to North Rhodope 351 during the exhumation of the Southern Rhodope Core Complex. In the junction area between 352 the NAT and the NAF, positive flower structures (Roussos and Lyssimachou 1991) suggest a 353 reactivation of pre-existing faults of the NAT at the propagating tip of the NAF. The dextral 354 strike-slip displacements that characterize the NAF become transtensional in the NAT with a 355 series of North-dipping normal faults oriented WNW-ESE that branch onto the sharp and 356 linear eastern border of the NAT (Fig. 6). The superposition of the GPS displacement field on 357 top of the map of Neogene basins (Fig.7) shows that the NAT separates two domains where 358 displacements are southward and low rate $(<0.5 \mathrm{~cm} / \mathrm{y})$ to the North and southwestward and 359 medium rates $(>2.1 \mathrm{~cm} / \mathrm{y})$ to the South. Syn-sedimentation rollover geometry of Neogene 360 basins of Southern Rhodope indicates a NE-SW direction of stretching in Pliocene (Brun and 361 Sokoutis 2007). Kinematic analysis of faults systems in North Aegean (Lyberis 1984; Lyberis 362 and Sauvage 1985; Mercier et al. 1987, 1989) revealed that a change in the direction of 363 stretching from NE-SW to N-S (Fig. 8) occurred in Lower Pleistocene. This suggests that the 364 present-day displacement pattern became fully installed rather recently, in Lower-Middle 
365 Pleistocene. A similar change in the direction of stretching from NE-SW to N-S is also 366 observed in the Southern Hellenides during the Pliocene (See Fig. 3 in Papanikolaou and 367 Royden 2007). Figure 6 shows that the Myrthes-Ikaria fault (MIF) is the offshore extend of 368 the onshore Ismir-Balikeshir transfer zone (IBTZ) (Sozbilir et al. 2010; Ersoy et al. 2012;

369 Uzel et al. 2013) (Fig. 6). Lower(?)-Upper Miocene sedimentary-volcanic basins were 370 deposited in this transtensional corridor, located at the northwestern border of the Menderes 371 Massif (Ersoy et al. 2012). Simultaneously, grabens developed in the Menderes, 372 accommodating a NE-SW direction of stretching. Without entering here into the complexities 373 of the paleomagnetic record of block rotations in IBTZ and Menderes (Uzel et al. 2015), it 374 must be mentioned that dextral strike-slip shear in IBTZ accommodated a CCW rotation of 375 the southern Menderes of around 30 (Pourteau et al. 2010; van Hinsbergen et al. 2010), 376 likely comparable to the $33^{\circ} \mathrm{CCW}$ rotation of the Naxos-Paros block in the Cyclades (Morris 377 and Anderson 1996) accommodated by dextral strike-slip offsets along the MIF (Philippon et 378 al. 2012, 2014). Over $450 \mathrm{~km}$, from Myrthes Basin to Balikeshir, this dextral strike-slip fault 379 zone was active since Middle Miocene -i.e. around 10 My before the arrival of the NAF in 380 the North Aegean. We lack of direct markers to identify when displacements ceased on this 381 fault. We may hypothesize that it should be around $5 \mathrm{Ma}$ when the NAF fully localized, 382 reaching the western part of Marmara Sea This would be in agreement with the last 383 exhumation ages recorded by low-temperature thermochronology (Fig. 5). The Myrthes384 Balikeshir fault zone accommodated the difference in amount of stretching between the two 385 domains that it separates. Therefore it is interesting to note that, in terms of displacement, the 386 bulk $50 \mathrm{~km}$ offset of dextral strike-slip along the fault that was estimated in the central 387 Cyclades (Philippon et al. 2014) is in rather good agreement with the $50 \mathrm{~km}$ of NE-SW 388 trending extension estimated in the southern part of the Menderes Massif (van Hinsbergen, 389 2010). 
In summary, the mode of extension during this second stage of back-arc extension is in

391

394

strong contrast with the one that characterizes the first stage. Extension passed in Middle

Miocene from the core complex mode to the wide rift mode (Buck 1991; Brun 1999), as demonstrated by the deposition of extensional or transtensional Neogene basins across the whole Aegean offshore and onshore. The interruption of ductile exhumation in Middle Miocene, in all types of metamorphic rocks (HT as well as HP) whatever their age of onset, as well as the segmentation of the metamorphic units and the deposition of Neogene basins on top of them suggest that the transition between the two modes of extension was not progressive and likely occurred in a rather short delay.

\section{Restoration of 45 My of back-arc extension}

Restorations of deformation in the shallow upper crust have demonstrated the difficulties and limitations inherent to this type of exercise. At lithosphere scale, like attempted here, restoration is face to more difficulties and depends even more than at smaller scales on the interpretation that is made, prior to restoration, of i) the tectonic setting in time and space of the domain to be restored and ii) the understanding of mechanical processes involved. In other words, such a restoration cannot be expected to put in evidence something that has not been identified and understood prior to restoration, whatever the particular techniques used for restoration. However, in spite of these limitations and in a case like the Aegean whose 3D evolution is rather complex, it is the best way: i) to test the coherence of the proposed interpretations, ii) to discuss their 3D implications, and iii) to make them more easily accessible and opened to critical assessment by anyone.

The 3D reconstruction of the 45 My history of back-arc extension presented in this section was carried out in two steps, in map view and then in cross-sections. It was performed manually using standard graphical techniques because a computer procedure appropriate for 
415 restoration at lithosphere scale does not exist yet. The two-step restoration, in map view and

416 in cross-section, was performed at 5, 15 and $45 \mathrm{Ma}$ for which enough geological and

417 geophysical data were available to satisfactorily constrain a model. An intermediate model at 41830 Ma was obtained by interpolation.

419 Restoration in map view was carried out using the data from references quoted in the two 420 previous sections plus: i) Geological map of Greece at various scales (IGME), ii) offshore 421 maps (synthesis by Mascle and Martin 1990), ii) paleomagnetic data (see compilations in: i) 422 Kissel and Laj 1988 and Van Hinsbergen et al. 2005 at Aegean scale, ii) Dimitriadis et al. 4231998 for northern Greece, Morris and Anderson 1996 for the Cyclades and Kissel et al. 1993 424 for Western Anatolia), iii) Principal directions of stretching and shear sense recorded in HT 425 and HP metamorphic rocks during subduction (Black arrows) and extensional exhumation 426 (White arrows) (Figs. 3 and 4). Colors of the restored maps are the same than those of the 427 present-day map (Fig.1). The darker blue band in Adria corresponds to the external fold and 428 thrust belt of the Pindos Nappe. All maps show the position of Black Sea and the location of 429 the rotation pole of Scutary-Pec (Albania) (Kissel et al. 1995) around which the Southern 430 Hellenides and western Cyclades rotated clockwise by $50^{\circ}$ since Oligocene (Kissel and Laj 431 1988; Van Hinsbergen et al. 2005). The present restoration integrates more detailed 432 restoration models dedicated to the Cyclades (Philippon et al. 2014) and to Northern 433 continental Greece (Kydonakis et al. 2015a).

434 The series of maps (Fig. 9) shows: i) the change in geometry and location of the Vardar 435 and Pindos suture zones, ii) the approximate position of the trench, iii) the development of 436 major strike-slip faults, in particular the Myrthes-Ikaria Fault (MIF) between 15 and 5 Ma and 437 the North Anatolia Fault (NAF) since $5 \mathrm{Ma}$ and iv) the location of Paleogene basins (in 438 orange). The present-day strong obliquity between stretching directions related to ductile 439 exhumation in Peloponnese and Crete is almost entirely restored into a single NE-trending 
440 direction at 5Ma. At $15 \mathrm{Ma}$, the stretching directions of Peloponnese, Crete and Cyclades are 441 all parallel and trending NNE with Crete located below the Cyclades. In northern Greece, the 442 progressive exhumation of the Southern Rhodope Core Complex occurred during the 443 deposition of the Thrace Basin (TB). The lateral transition between these two major 444 geological features of the North Aegean was likely accommodated by sinistral transcurrent 445 displacements along the North Aegean Trench (NAT), from 45 to $5 \mathrm{Ma}$. At $30 \mathrm{Ma}$, all the 446 Paleogene basins (Mesohellenic Trough (MHT), North Aegean Trough (NAT), Xanthi Basin 447 (XB) and Thrace Basin (TB)) are close to each other, forming a band slightly oblique to the 448 trend of the suture zones of Vardar and Pindos. Our restoration is in a rather good agreement 449 with the one of Royden and Papanikolaou (2011; their Fig. 15), up to lower Oligocene, but at 450 strong variance with the one of van Hinsbergen and Schmid (2012; their Fig. 12) that requires 451 a component of EW stretching across the whole Aegean accommodated by N-S or NE-SW 452 trending extensional detachments, giving in the southern Aegean an arc-parallel extension up 453 to $650 \mathrm{Km}$ between $15 \mathrm{Ma}$ and present (i.e. more EW displacement than the bulk amount of 454 trench retreat). In addition, the van Hinsbergen and Schmid's model, contrary to our model, 455 totally ignores the kinematics of HP-metamorphic rocks exhumation, as their model implied 456 stretching directions trending perpendicular or strongly oblique to the stretching directions 457 recorded in rocks.

458 Restoration in cross-section was done using the following input data: i) restored maps 459 (previous section), ii) peak pressures recorded in high pressure metamorphic rocks (see 460 review in Jolivet and Brun 2010 and Philippon et al. 2012), iii) present-day crustal thickness 461 (Tirel et al. 2004) and iv) present-day geometry of the top slab surface from S-wave 462 tomography (Salaün 2011). Two parallel sections oriented NE-SW have been restored: i) 463 from NW Peloponnese to North Rhodope (Section A) and ii) from Southeast Peloponnese to 464 the West of Marmara Sea (section B) (Fig. 10). The present-day geometry of the slab in 
465 section A shows a fold that passes laterally to a slab tear in section B. In section A, extension

466 is mostly located to the North of the Vardar suture zone (Vardar-Thermaikos Gulf and 467 SRCC). At $50 \mathrm{Ma}$, the Pelagonian crust that has been entirely subducted starts to delaminate 468 from the underlying mantle allowing the asthenosphere to flow below the crust. As a 469 consequence, fast and strong crustal heating, up to partial melting, strongly weakened the 470 crust. At $45 \mathrm{Ma}$, after the subduction of the narrow Pindos oceanic domain, the Adria crust 471 was dominantly subducted and core complex extension (SRCC) started at the back of the 472 thrust wedge, controlled by the Kerdylion Detachment. At $15 \mathrm{Ma}$, core complex extension 473 gave place to wide rift mode of extension with deposition of Neogene basins, the larger one 474 being the Vardar-Thermaikos Gulf basin. Along this section, located to the West of the 475 Corinth Gulf, trench retreat reached around $300 \mathrm{Km}$. Most of the extension was located in the 476 North Aegean and, conversely, the Adria crust (Southern Hellenides) was only weakly 477 extended. The section B shows the same sequence of tectonic events but with two major 478 differences: i) trench retreat reached around $500 \mathrm{Km}$ and extension affected the full Adria 479 crustal block and ii) to the North, instead of a core complex, extension gave birth to the 480 Thrace Basin on top of Rhodopia. The series of sections illustrates that the exhumation of 481 high-pressure metamorphic rocks of Adria and partly Pelagonia occurred entirely in 482 extension. Between 45 and $15 \mathrm{Ma}$, the whole initial thrust pile collapsed southward and both 483 Pelagonia and Adria underwent a layer-parallel top to North sense of shear bringing them in a 484 lower crustal depth. Since $15 \mathrm{Ma}$, the southern part of the extending thrust wedge that was 485 located to the South of the slab tear, underwent a strong distributed extension that achieved 486 the exhumation of metamorphic rocks up to surface. 
Eocene and Middle Miocene and second since Middle Miocene. The first stage, prior to

491 Middle Miocene, is illustrated by the deposition of Paleogene basins (Fig. 2) and the simultaneous exhumation of high-temperature and high-pressure metamorphic rocks in a core complex northward and a blueschist belt southward. This occurred in two steps: i) In Middle

494

500

501 502

Eocene (45 Ma) started the exhumation of the SRCC in the Rhodope (Fig. 3) and the CBU in the Cyclades (Fig. 4) and in Lower Miocene (around $23 \mathrm{Ma}$ ) the exhumation of the CCCC in the Cyclades (Fig. 3) and the PQN blueschists in Peloponnese and Crete (Fig. 4). During the second stage, since Middle Miocene, the HP and HT metamorphic units exhumed during the first stage were segmented dominantly in transtension, synchronous with Neogene basin deposition.

The restoration of displacements that is well constrained in continental Greece and central Aegean by numerous paleomagnetic data, kinematic indicators in metamorphic rocks and geochronological data shows that an acceleration of trench retreat started in Middle Miocene (Fig. 11). The rate of trench retreat that was rather low, around $0.6 \mathrm{~cm} . \mathrm{y}^{-1}$, during the first stage of extension increased to around $1.7 \mathrm{~cm} . \mathrm{y}^{-1}$ between Middle Miocene and Pliocene to reach $3.2 \mathrm{~cm} . \mathrm{y}^{-1}$ during the last $5 \mathrm{Ma}$. This is in agreement with the "dramatic acceleration" of back-arc extension deduced by Van Hinsbergen et al. (2010) from their study of the Menderes Massif in western Anatolia.

This acceleration of trench retreat (i.e. extensional boundary displacement), first by a factor 2 after Middle Miocene and then by a factor 5 after Pliocene, was likely responsible for the observed change in the mode of extension, from localized to distributed (i.e. from core complex to wide rift; Buck 1990; Brun 1999; Tirel et al. 2006, 2008; Gueydan et al. 2008; Kydonakis et al. 2015a). Mechanical modeling of the extension of a two-layer brittle-ductile system shows that an increase in strain rate increases the strength of the ductile layer and 
514 consequently the coupling between the brittle and ductile layers, giving a transition from 515 localized to distributed extension (Brun 1999; Schueller et al. 2005, 2010).

516 In addition to this major change in the style of extension, it is interesting to note that 517 the difference in $\mathrm{P} / \mathrm{T}$ ratios between the high-pressure metamorphic rocks of Cyclades and 518 Crete agrees well with an increase in the velocity of trench retreat (Gueydan et al. 2009). The acceleration of trench retreat is probably related to a lateral tearing of the 520 Hellenic slab below western Anatolia (Brun and Sokoutis 2010; Van Hinsbergen et al. 2010) 521 identified by P-wave tomographic models of the upper mantle (Piromallo and Morelli 2003; 522 Biryol et al. 2011). The improved resolution of mantle structure provided by S-wave 523 tomographic modeling (Salaün et al. 2012) allowed a mapping of the slab tear with three main 524 trends (Salaün 2011) (Fig. 10): WNW-ESE, below the central part of North Aegean Sea, and 525 NNW-SSE and E-W almost parallel to the two mean coastline trends of Southwest Anatolia. 526 Section B (Fig. 10) shows the geometry of the top slab below the North Aegean. Whereas the 527 exact timing of slab tearing is difficult to constrain, the sudden change in the mode of 528 extension that is associated with the acceleration of slab retreat strongly supports that slab 529 tearing should have started to develop earlier, possibly in Early Miocene, to become fully 530 efficient from $15 \mathrm{Ma}$ onward.

531 The transtensional deformation pattern that results from the interaction between 532 Hellenic trench retreat and Anatolia westward displacement and that is still active in the 533 Aegean took place in Middle Miocene, showing that the westward displacement Anatolia was 534 coeval with the acceleration of trench retreat. Whereas the North Anatolian fault plays a 535 major role in the present-day kinematic pattern, the Myrthes-Ikaria-IBTF was the first large 536 dextral strike-slip fault zone to develop. Its location close to the Izmir-Ankara suture zone and 537 parallel to it suggests that the suture zone was acting as weak zone able to localize 538 displacements at the onset of Anatolia westward displacement, as illustrated in the laboratory 
539 experiments of Philippon et al. (2014). However, this interaction between two plate boundary

540 displacements raises a still opened fundamental issue: What is the dynamic relationship

541 between slab tearing and Anatolia displacement? Which one controlled the development of 542 the other?

543

\section{Acknowledgements}

545 J-P Brun thanks Ali Polat for inviting the paper. Research was financially supported 546 by ANR EGEO (ANR-06-BLAN-0156) lead by L. Jolivet (J-PB, FG and MP), the European 547 Union FP7 Marie Curie ITN “TOPOMOD” contract 264517, lead by C. Faccenna (J-PB, CF, 548 FG, KK and DS) and by the Netherlands Research Centre for Integrated Solid Earth Science 549 (DS). We thank the guest editor C. Şengör, D. Van Hinsbergen and an anonymous reviewer 550 for their comments and suggestions of improvement. 


\section{References}

554 Armijo, R., Meyer, B., Hubert, A., and Barka, A. 1999. Westward propagation of the north 555 Anatolian into the northern Aegean: timing and kinematics. Geology, $27: 267-270$.

556 Avigad, D., Ziv, A., and Garfunkel, Z. 2001. Ductile and brittle shortening, extension-parallel 557 folds and maintenance of crustal thickness in the central Aegean (Cyclades, Greece). 558 Tectonics, $20: 277-287$. doi:10.1029/2000TC001190.

559 Bache, F., Popescu, S.-M., Rabineau, M., Gorini, C., Suc, J.-P., Clauzon, G., Olivet, J.-L., 560 Rubino, J.-L., Melinte-Dobrinescu, M.C., Estrada, F., Londeix, L., Armijo, R., Meyer, B., 561 Jolivet, L., Jouannic, G., Leroux, E., Aslanian, D., Baztan, J., Dos Reis, A.T., Mocochain, 562 L., Dumurdžanov, N., Zagorchev, I., Lesić, V., Tomić, D., Cağatay, M.N., Brun, J.-P., 563 Sokoutis, D., Ucarkus, G., and Cakir, Z. 2011. A two-step process for the reflooding of the 564 Mediterranean after the Messinian salinity crisis. Basin Research, 23 : 1-29, doi: $565 \quad 10.1111 / \mathrm{j} .1365-2117.2011 .00521 . \mathrm{x}$

566 Bargnesi, E.A., Stockli, D.F., Neil Mancktelow, N., and Soukis, K. 2013. Miocene core 567 complex development and coeval supradetachment basin evolution of Paros, Greece, 568 insights from (U-Th)/He thermochronometry. Tectonophysics, 595-596 : 165-182.

569 Beniest, A., Brun, J.-P., Jeroen Smit, J., Deschamps, R., Hamon, Y., Crombez, V., and Gorini, 570 C. 2015. Structure and seismic stratigraphy of deep Tertiary basins in the northern Aegean 571 Sea. Geophysical Research Abstract, 17, EGU2015-746.

572 Biryol, C.B., S.L., Zandt, G., and Özacar, A.A. 2011. Segmented African lithosphere beneath 573 the Anatolian region inferred from teleseismic P-wave tomography. Geophysical Journal $574 \quad$ International, $184: 1037-105$.

575 Bourcart, M. J. 1919. Sur la présence du Priabonien dans la région SE Salonique, Comptes 576 Rendus de l'Académie des Sciences, Paris, 855-856.

577 Brix, M.R., Stöckhert, B., Seidel, E., Theye, T., Thomson, S.N., and Küster, M. 2002. 
578

580

581

582

583

584

585

586

587

588

589

590

591

592

593

594

595

596

597

598

599

600

601

602

Thermobarometric data from a fossil zircon partial annealing zone in high pressure-low temperature rocks of eastern and central Crete, Greece. Tectonophysics, 349 : 309-326.

Brun, J.-P. 1999. Narrow rifts versus wide rifts: Inferences for the mechanics of rifting from laboratory experiments. Philosophical Transactions of the Royal Society, London, Ser. A, $357: 695-712$.

Brun, J.-P., and Faccenna, C. 2008. Exhumation of high-pressure rocks driven by slab rollback. Earth and Planetary Science Letters, 272 : 1-7. doi:10.1016/j.epsl.2008.02.038

Brun, J.-P., and Sokoutis, D. 2007. Kinematics of the Southern Rhodope Core Complex (north Greece). International Journal of Earth Sciences, 96 : 1079-1099.

Brun, J.-P., and Sokoutis, D. 2010. 45 m.y. of Aegean crust and mantle flow driven by trench retreat. Geology, 38 : 815-818. doi: 10.1130/G30950.1.

Buck, W.R. 1991. Modes of continental lithospheric extension, Journal of Geophysical Research, 96 : 20161 - 20178.

Buick, I.S. 1991. Mylonite fabric development on Naxos, Greece. Journal of Structural Geology, 13 : 643-655.

Burg, J.-P. 2011. Rhodope: From Mesozoic convergence to Cenozoic extension. Review of petro-structural data in the geochronological frame. In: (Eds.) Emmanuel Skourtsos and Gordon S. Lister, Journal of the Virtual Explorer, 39 : paper 1. doi:10.3809/jvirtex. 2011.00270

Carbotte, S.M., Arko, R., Chayes, D.N., Haxby, W., Lehnert, K., O’Hara, S., Ryan, W.B.F., Weissel, R.A., Shipley, T., Gahagan, L., Johnson, K., and Shank, T. 2004. New integrated Data Management System for Ridge 2000 and MARGINS Research, Eos Transactions. AGU, 85, 51, 553, doi : 10.1029/2004EO510002.

Carras, N., and Georgala, D. 1998. Upper Jurassic to Lower Cretaceous Carbonate Facies of African Affinities in a Peri-European Area: Chalkidiki Peninsula, Greece, Facies, 38 : 153 - 
164.

604 Channell, J.E.T., and Kozur, H. 1997. How many oceans? Meliata, Vardar, and Pindos oceans 605 in Mesozoic Alpine paleogeography. Geology, 25 : 183-186.

606 Denèle, Y., Lecomte, E., Jolivet, L., Lacombe, O., Labrousse, L., Huet, B., and Le Pourhiet, 607 L. 2011. Granite intrusion in a metamorphic core complex: the example of the Mykonos 608 laccolith (Cyclades, Greece). Tectonophysics, 501 : 52-70. http://dx.doi.org/ $609 \quad 10.1016 / j$.tecto.2011.01.013.

610 Chiotis, E.D. 1984. A Middle Miocene thermal event in northern Greece confirmed by 611 coalification measurements. In : Dixon, J.E. and Robertson, A.H.F. (Eds) The Geological 612 Evolution of the Eastern Mediterranean. Geological Society, London, Special Publications, $613 \quad 17: 815-818$. doi:10.1144/GSL.SP.1984.017.01.66.

614 Dercourt, J., Ricou, L.E., and Vrielynck, B. 1993. Atlas Tethys Paleoenvironmental Maps, 615 Beicip-Franlab. Deschamps, R., Hamon, Y., Darre, T., Gorini, C., 2013. Caractérisation 616 des séries lacustres du Miocène Supérieur de l'Ile de Samos. Un exemple de paléolac 617 alcalin et salin, in: 14eme Congrès Français de Sédimentologie, Paris (Ed. ASF), 73 : 118.

618 Dewey, J. F., and Şengör, A. C. 1979. Aegean and surrounding regions: complex multiplate 619 and continuum tectonics in a convergent zone. Geological Society of America Bulletin, 90 $620 \quad: 84-92$

621 Dimitriadis, S. 1989. Sillimanite grade metamorphism in the Thassos Island, Rhodope Massif, 622 Greece, and its regional significance. Geologica Rhodopica, $1: 190-201$

623 Dimitriadis, S., Kondopoulou, D., and Atzemoglou, A. 1998. Dextral rotation and 624 tectonomagmatic evolution of the southern Rhodope and adjacent regions (Greece). 625 Tectonophysics, $299: 159-173$

626 Dinter, D.A., and Royden, L. 1993. Late Cenozoic extension in northeastern Greece: Strymon 627 Valley detachment system and Rhodope metamorphic core complex. Geology, $21: 45-48$ 
628 Dinter, D.A., Macfarlane, A., Hames, W., Isachsen C., Bowring, S., and Royden, L. 1995. U$629 \mathrm{~Pb}$ and $\mathrm{Ar} / \mathrm{Ar}$ geochronology of the Symvolon granodiorite: Implications for the thermal 630 and structural evolution of the Rhodope metamorphic core complex, northeastern Greece. 631 Tectonics, $14: 886-908$

632 Doutsos, T., Koukouvelas, I., Zelilidis, A., and Kontopoulos, N. 1994. Intracontinental 633 wedging and post-orogenic collapse in Mesohellenic trough. - Geologische Rundschau, 83 $634: 257-275$

635 Duchêne, S., Aïssa, R., and Vanderhaeghe, O. 2006. Pressure-temperature-time evolution of 636 metamorphic rocks from Naxos (Cyclades, Greece): constraints from Thermobarometry 637 and $\mathrm{Rb} / \mathrm{Sr}$ dating. Geodynamica Acta, $19: 299-319$.

638 Ersoy, E.Y., Helvaci, C., Uysal, I., Karaoğlu, Ö., Palmer, M.R., and Dindi, F. 2012. 639 Petrogenesis of the Miocene volcanism along the Izmir-Balıkesir Transfer Zone in western 640 Anatolia, Turkey: implications for origin and evolution of potassic volcanism in 641 postcollisional areas. Journal of Volcanology and Geothermal Research, 241-242 : 21-38.

642 Faccenna, C., Jolivet, L., Piromallo, C., and Morelli, A. 2003. Subduction and the depth of 643 convection in the Mediterranean mantle. Journal of Geophysical Research, 108 : 2099. $644 \quad$ http://dx.doi.org/10.1029/2001JB001690.

645 Faccenna C., Becker T.W., Auer L., Billi A., Boschi L., Brun J.-P., Capitanio F.A., Funiciello 646 F., Horvàth F., Jolivet L., Piromallo C., Royden L., Rossetti F., and Serpelloni E. 2014. 647 Mantle dynamics in the Mediterranean. Review of Geophysics, doi: $648 \quad 10.1002 / 2013 R G 000444$

649 Ferrière, J., Reynaud, J.-Y., Pavlopoulos, A., Bonneau, M., Migiros. G., Chanier F., Proust, 650 J.-N., and Gardin, S. 2004. Geologic evolution and geodynamic controls of the Tertiary 651 intramontane piggyback Meso-Hellenic basin, Greece. Bulletin de la Société Géologique 652 de France, $175: 361-381$. 
653 Gautier, P., and Brun, J.-P. 1994. Crustal-scale geometry and kinematics of late-orogenic 654 extension in the central Aegean (Cyclades and Evvia Island). Tectonophysics, 238 : $655 \quad 399-424$.

656 Gautier, P., Ballèvre, M., Brun J.-P. and Jolivet, L. 1990. Cinématique de l'extension ductile à 657 Naxos et Paros (Cyclades). C.R. Acad. Sci., Paris, 310 : 147-153.

658 Gautier, P., Brun, J.-P., and Jolivet, L., 1993. Structure and kinematics of Upper Cenozoic 659 extensional detachment on Naxos and Paros (Cyclades Islands, Greece). Tectonics, 12 : $660 \quad 1180-1194$.

661 Goldsworthy, M., Jackson, J., and Haines, J. 2002. The continuity of active fault systems in 662 Greece. Geophysical Journal International, $148: 596-618$.

663 Görür, N., and Okay, A.I. 1996. A fore-arc origin for the Thrace Basin, NW Turkey. 664 Geologische Rundschau. 85 : 662-668.

665 Gueydan, F., C. Morency, and J.P. Brun, 2008. Continental rifting as a function of lithosphere 666 mantle strength, Tectonophysics, $460: 83-93$.

667 Gueydan, F., Le Garzic, E. and Carry, N., 2009. P/T ratio in high-pressure rocks as a function 668 of dip and velocity of continental subduction. Lithosphere, $1: 282-290$.

669 Hatzfeld, D. 1999. The present-day tectonics of the Aegean as deduced from seismicity. In:

670 Durand, B., Jolivet, L., Horvath, F \& Séranne, M. (eds) The Mediterranean Basins: 671 Tertiary Extension within the Alpine Orogen. Geological Society, London, Special 672 Publications, $156: 415-426$.

673 Hollenstein, C., Müller, M.D., Geiger, A., Kahle, and H.-G. 2008. Crustal motion and 674 deformation in Greece from a decade of GPS measurements, 1993-2003. Tectonophysics, $675449: 17-40$, http://dx.doi.org/10.1016/j.tecto.2007.12.006.

676 Hubert-Ferrari, A., King, G., Manighetti, I., Armijo, R., Meyer, B., and Tapponnier, P. 2003. 
677 Long-term Elasticity in the Continental Lithosphere; Modelling the Aden Ridge 678 Propagation and the Anatolian Extrusion Process. Geophysical Journal International, 153 : $679 \quad 111-132$.

680 Huet, B., Labrousse, L., and Jolivet, L. 2009. Thrust or detachment? Exhumation processes 681 in the Aegean: Insight from a field study on Ios (Cyclades, Greece). Tectonics, 28 , 682 TC3007, doi:10.1029/2008TC002397.

683 Jolivet, L., and Brun, J.-P. 2010. Cenozoic geodynamic evolution of the Aegean. International 684 Journal of Earth Sciences, 99 : 109-138. doi:10.1007/s00531-008-0366-4.

685 Jolivet, L., and Faccenna, C. 2000. Mediterranean extension and the Africa-Eurasia collision. 686 Tectonics, $19: 1095-1106$.

687 Jolivet, L., Trotet, F., Monié, P., Vidal, O., Goffé, B., Labrousse, L., Agard, P., and Ghorbal, 688 B. $2010 \mathrm{a}$ Along-strike variations of $\mathrm{P}-\mathrm{T}$ conditions in accretionary wedges and syn689 orogenic extension, the HP-LT Phyllite-Quartzite Nappe in Crete and the Peloponnese. 690 Tectonophysics, $480: 133-148$. doi:10.1016/j.tecto.2009.10.002.

691 Jolivet, L., Lecomte, E., Huet, B., Denèle, Y., Lacombe, O., Labrousse, L., Le Pourhiet, L., 692 and Mehl, C. 2010b. The North Cycladic detachment system. Earth and Planetary Science 693 Letters, 289 : 87-104. http://dx.doi.org/10.1016/j.epsl.2009.10.032.

694 Jolivet, L., Faccenna, C., Huet, B., Labrousse, L., Le Pourhiet, L., Lacombe, O., Lecomte, E., 695 Burov, E., Denèle, Y., Brun, J.-P., Philippon, M., Paul, A., Salaün, G., Karabulut, H., 696 Piromallo, C., Monié, P., Gueydan, F., Okay, A.I., Oberhänsli, R., Pourteau, A., Augier, 697 R., Gadenne, L., and Driussi, O. 2013. Aegean tectonics: Strain localisation, slab tearing 698 and trench retreat. Tectonophysics, $597: 1-33$. doi:10.1016/j.tecto.2012.06.011

699 Jones, K.D. 1971. An outline of the geology of the islands of Mytilini and Chios - in:

700 Campbell, A.S. (ed.) - Geology and history of Turkey - Petroleum Exploration Society of 701 Libya, Tripoli: 275-282. 
702 Keay, S., Lister, G., and Buick, I. 2001. The timing of partial melting, Barrovian

703 metamorphism and granite intrusion in the Naxos metamorphic core complex, Cyclades,

$704 \quad$ Aegean Sea, Greece. Tectonophysics, $342: 275-312$.

705 Kilias, A., Falalakis, G., Sfeikos, A., Papadimitriou, E., Vamvaka, A., and Gkarlaouni, C.

706 2013. The Thrace basin in the Rhodope province of NE Greece - A tertiary

707 supradetachment basin and its geodynamic implications. Tectonophysics, 595-596 : 90-

$708 \quad 105$.

709 Kissel, C., and Laj, C., 1988. The Tertiary geodynamic evolution of the Aegean arc: a 710 paleomagnetic reconstruction. Tectonophysics, $146: 183-201$.

711 Kissel, C., Averbuch, O., Frizon de Lamotte, D., Monod, O., and Allerton, S., 1993.

712 Preliminary paleomagnetic evidence of a post-Eocene clockwise rotation of the Western

713 Taurides thrust belt, east of the Isparta reentrant (Southern Turkey). Earth and Planetary

$714 \quad$ Science Letters. $117: 1-14$.

715 Kissel, C., Speranza, F., and Milicevic, V. 1995. Paleomagnetism of external southern

716 Dinarides and northern Albanides: implications for the Cenozoic activity of the Scutari-

717 Pec shear zone. Journal of Geophysical Research, 100 : 14999-15007.

718 Kolocotroni, C., and Dixon, J. 1991. The origin and emplacement of the Vrondou granite,

719 Serres, NE Greece. Bulletin of the Geological Society of Greece, 25 : 469-483.

720 Koufos, G.D., Kostopoulos, D.S., and Vlachou, Th.D. 2009. The Late Miocene Mammal

721 Faunas of the Mytilinii Basin, Samos Island, Greece: New Collection. 16. Biochronology.

722 — Beiträge zur Paläontologie, $31: 397-408$.

723 Koukouvelas, I.K., and Aydin, A. 2002. fault structure and related basins of the North Aegean

724 Sea and its surroundings. Tectonics, $21: 1046$. http://dx.doi.org/10.1029/ 2001TC901037.

725 Kydonakis, K., Gallagher, K., Brun J.P., Jolivet, M., Gueydan, F. and Kostopoulos, D. 2014.

726 Upper Cretaceous exhumation of the western Rhodope Metamorphic Province (Chalkidiki 
727 Peninsula, northern Greece), Tectonics, 33, doi:10.1002/2014TC003572.

728 Kydonakis, K., Brun, J.-P., and Sokoutis, D. 2015a. North Aegean core complexes, the 729 gravity spreading of a thrust wedge. Journal of Geophysical Research, Solid Earth, 120, 730 doi:10.1002/2014JB011601.

731 Kydonakis, K., Brun, J.-P., Sokoutis, D. and Gueydan, F. 2015b. Kinematics of Cretaceous 732 subduction and exhumation in the western Rhodope (Chalkidiki block). Tectonophysics, $733 \quad 665: 218-235$

734 Kydonakis, K., Moulas, E., Chatzitheodoridis, E., Brun, J.-P. and Kostopoulos, D. 2015c. 735 First-report on Mesozoic eclogite-facies metamorphism preceding Barrovian overprint 736 from the western Rhodope (Chalkidiki, northern Greece). Lithos, 220-223 : 147-163. 737 http://dx.doi.org/10.1016/j.lithos.2015.02.007

738 Kyriakopoulos, K., Pezzino, A., and Moro, A.D. 1989. Rb-Sr geochronological, petrological 739 and structural study of the Kavala plutonic complex (N. Greece). Bulletin of the 740 Geological Society of Greece, XXIII : 545-560

741 Kyriakopoulos, K.G., Magganas, A.C., Norelli, P., Bigazzi., G., Moro, A.D., and Kokkinakis, 742 A. 1997. Thermochronological evolution of Symvolon and Pangeon pluton and their 743 country rocks, Kavala area, N. Greece: an apatite fission track analysis, Neues Jahrbuch für $744 \quad$ Mineralogie, H11 : 519 - 529.

745 Lalechos, N. 1986. Correlations and observations in molassic sediments in onshore and 746 offshore areas of northern Greece. Lithos, $56: 89-99$

747 Lecomte, E., Jolivet, L., Lacombe, O., Denèle, Y., Labrousse, L., and Le Pourhiet, L. 2010.

748 Geometry and kinematics of a low-angle normal fault on Mykonos island (Cyclades, 749 Greece): evidence for slip at shallow dip. Tectonics, 29, TC5012. http://dx.doi.org/ $750 \quad 10.1029 / 2009 T C 002564$. 
751 Le Pichon, X., and Angelier, J. 1981. The Aegean Sea. Philos. Philosophical Transactions of 752 the Royal Society, London, Ser. A $300: 357-372$.

753 Liati, A., 2005. Identification of repeated Alpine (ultra) high-pressure metamorphic events by

754 U-Pb SHRIMP geochronology and REE geochemistry of zircon: the Rhodope zone of

755 Northern Greece. Contribution to Mineralogy and Petrology, 150 : 608-630

756 Lyberis, N. 1984. Tectonic evolution of the North Aegean trough, Geological Society, $757 \quad$ London, Special Publications, $17: 709-725$.

758 Lyberis, N., and Sauvage, J. 1985. Tectonic evolution of the North Aegean area during the 759 Plio-Pleistocene. Bulletin de la Société Géologique de France, I : 581-595.

760 Maravelis, A., and A Zelilidis, A. 2011. Organic geochemical characteristics of the late 761 Eocene-early Oligocene submarine fans and shelf deposits on Lemnos Island, NE Greece. 762 Journal of Petroleum Science and Engineering, $71: 160-168$.

763 Marsellos, A.E., Min, K., and Foster David, A. 2014. Rapid Exhumation of High-Pressure 764 Metamorphic Rocks in Kythera-Peloponnese (Greece) Revealed by Apatite (U-Th)/He 765 Thermochronology. The Journal of Geology, $122: 381-396$.

766 Mascle, J., and Martin, L. 1990. Shallow structure and recent evolution of the Aegean Sea: A 767 synthesis based on continuous reflection profiles. Marine Geology, 94 : 271-299. doi: $768 \quad 10.1016 / 0025-3227(90) 90060-W$

769 McClusky, S., Balassanian, S., Barka, A., Demir, C., Ergintav, S., Georgiev, I., Gurkan, O., 770 Hamburger, M., Hurst, K., Kahle, H., Kastens, K., Kekelidze, G., King, R., Kotzev, V., 771 Lenk, O., Mahmoud, S., Mishin, A., Nadariya, M., Ouzounis, A., Paradissis, D., Peter, Y., 772 Prilepin, M., Reilinger, R., Sanli, I., Seeger, H., Tealeb, A., Toksöz, M. N., and Veis G. 773 2000. Global Positioning System constraints on plate kinematics and dynamics in the 774 eastern Mediterranean and Caucasus. Journal of Geophysical Research, Solid Earth, 105 : $775 \quad 5695-5719$. 
776 McKenzie, D.P. 1972. Active tectonics of the Mediterranean region. Geophysical Journal of 777 the Royal Astronomical Society, $30: 109-185$.

778 McKenzie, D. P. 1978. Active tectonics of the Alpine Himalayan Belt, the Aegean Sea and 779 surrounding regions. Geophysical Journal of the Royal Astronomical Society, 55 : $217-$ $780 \quad 252$.

781 Mercier, J.-L., Sorel, D., and Simeakis, K. 1987. Change in the state of stress in the overriding 782 plate of a subduction zone: the Aegean Arc from the Pliocene to the present. Annales 783 Tectonicae, $1: 20-39$.

784 Mercier, J.-L., Sorel, D., Vergely, P., and Simeakis, K. 1989. Extensional tectonic regimes in 785 the Aegean basins during the Cenozoic. Basin Research, 2 : 49-71.

786 Morris, A., and Anderson, M. 1996. First palaeomagnetic results from the Cycladic Massif, 787 Greece, and their implications for Miocene extension directions and tectonic models in the 788 Aegean. Earth and Planetary Science Letters, 142 : 397-408.

789 Mposkos, E., and Kostopoulos, D. 2001. Diamond, former coesite and supersilicic garnet in 790 metasedimentary rocks from the Greek Rhodope: a new ultrahigh-pressure metamorphic 791 province established. Earth and Planetary Science Letters, 192 : 497-506.

792 Müller, M.D., Geiger, A., Kahle, H.-G., Veis, G., Billiris, H., Paradissis, D., and Felekis, S. 793 2013. Velocity and deformation fields in the North Aegean domain, Greece, and 794 implications for fault kinematics, derived from GPS data 1993-2009. Tectonophysics, 597$795 \quad 598: 34-49$. http://dx.doi.org/10.1016/j.tecto.2012.08.003

796 Nagel, T. J., Schmid, S., Janak, M., Froitzheim, N., Jahn-Awe, S., and Georgiev, N. 2011.

797 The exposed base of a collapsing wedge: The Nestos Shear Zone (Rhodope Metamorphic

798 Province, Greece). Tectonics, 30 : TC4009, doi: 10.1029/2010TC002815.

799 Nyst, M., and Thatcher, W. 2004. New constraints on the active tectonic deformation of the 800 Aegean. Journal of Geophysical Research, Solid Earth, 109 : B11406, 
801

802 Papanikolaou, D.J., and Royden, L.H. 2007. Disruption of the Hellenic arc: Late Miocene 803 extensional detachment faults and steep Pliocene-Quaternary normal faults-Or what 804 805 806 807 808 809

doi:10.1029/2003JB002830. happened at Corinth? Tectonics, 26 : TC5003. doi:10.1029/2006TC002007.

Papanikolaou, D., Alexandri. M., and Nomikou. P. 2006. Active faulting in the north Aegean basin. in Dilek Y. and Pavlides S. eds. Postcollisional tectonics and magmatism in the Mediterranean region and Asia: Geological Society of America, Special Paper, 409 : 189209. doi: I 0.1130n006.2409( 11 ).

Papanikolaou, D., Alexandri, B., Nomikou, P., and Ballas, D. 2002. Morphotectonic structure of the western part of the North Aegean Basin based on swath bathymetry. Marine Geology, 190 : 465-492.

Parra, T., Vidal, O., and Jolivet, L., 2002. Relation between the intensity of deformation and rétrogression in blueschist metapelites of Tinos Island (Greece) evidenced by chloritemica local equilibria. Lithos, $63: 41-66$.

Piromallo, C., and Morelli, A., 2003. P wave tomography of the mantle under the AlpineMediterranean area. Journal of Geophysical Research, 108, 2065, doi:10.1029/2002JB001757.

Philippon, M., Brun, J.P., and Gueydan F. 2012. Deciphering subduction from exhumation in the segmented Cycladic Blueschist Unit (Central Aegean, Greece). Tectonophysics, 524 : 116-134, doi:10.1016/j.tecto.2011.12.025

Philippon, M., Brun, J.-P., Gueydan, F. and Sokoutis, D. 2014. The interaction between Aegean back-arc extension and Anatolia escape since Middle Miocene. Tectonophysics, 631 : 176-188, doi:10.1016/j.tecto.2014.04.039

Piromallo, C., and Morelli, A. 2003. P wave tomography of the mantle under the AlpineMediterranean area. Journal of Geophysical Research, Solid Earth, 108 : 2065. 
826 Pourteau, A., Candan, O. and Oberhänsli, R. 2010. High $\square$ pressure metasediments in central

827 Turkey: Constraints on the Neotethyan closure history. Tectonics, 29, TC5004,

828 doi:10.1029/2009TC002650

829 Ring, U., Okrusch, M., and Will, T. 2007. Samos Island, Part I: metamorphosed and 830 nonmetamorphosed nappes, and sedimentary basins. Journal of the Virtual Explorer, 27 : $831 \quad$ paper 5. doi:10.3809/jvirtex.2007.00180.

832 Rosenbaum, G., and Ring, U. 2007. Structure and metamorphism of Amorgos: a field 833 excursion. Journal of the Virtual Explorer, 27 : Paper 7.

834 Roussos, N. 1994. Stratigraphy and paleogeographic evolution of Palaeocene molassic basins 835 of N. Aegean. Bulletin of the Geological Society of Greece, XXX : 275-294.

836 Roussos, N. and Lyssimachou, T. 1991. Structure of the Central North Aegean Trough: an 837 active strike-slip deformation zone. Basin Research, $3: 39-48$.

838 Royden, L.H. 1993. The tectonic expression slab pull at continental convergent boundaries. 839 Tectonics, $12: 629-638$.

840 Royden, L.H. and Papanikolaou, D.J. 2011. Slab segmentation and late Cenozoic disruption 841 of the Hellenic arc. Geochemistry, Geophysics, Geosystems, 12 : Q03010, doi: $842 \quad 10.1029 / 2010 G C 003280$.

843 Sakellariou, D., Mascle, J. and Lykousis, V. 2013. Strike slip tectonics and transtensional 844 deformation in the Aegean region and the Hellenic arc: preliminary results. Bulletin of the 845 Geological Society of Greece, XLVII, Proceedings of the 13th International Congress, 846 Chania, Sept. 2013.

847 Salaün, G. 2011. Structure et déformation du manteau supérieur de la région Egée-Anatolie 848 par tomographie en ondes de Rayleigh. PhD Thesis University of Grenoble.

849 Salaün, G., Pedersen, H., Paul, A., Farra, V., Karabulut, H., Hatzfeld, D., Childs, D.M., 850 Pequegnat, C., and the SIMBAAD Team 2012. High-resolution surface wave tomography 
851 beneath the Aegean-Anatolia region: constraints on upper mantle structure. Geophysical

852 Journal International, $190 \quad: \quad 406-420 . \quad$ http://dx.doi.org/10.1111/j. 1365$853 \quad$ 246X.2012.05483.x.

854 Schueller, S., F. Gueydan, and P. Davy, 2005, Brittle-ductile coupling: Role of ductile 855 viscosity on brittle fracturing. Geophysical Research Letters, 32, (L10308), 856 doi:10.1029/2004GL022272.

857 Schueller, S., Gueydan, F., and Davy. P. 2010. Mechanics of the transition from localized to 858 distributed fracturing in layered brittle-ductile systems. Tectonophysics, $484: 48-59$. 859 doi:10.1016/j.tecto.2009.09.008

860 Sengör, A.M.C., Tüysüz, O., Imren, C., Sakınç, M., Eyidogan, H., Görür, N., Le Pichon, X., 861 and Rangin, C. 2005. The North Anatolian Fault: A New Look. Annual Review of Earth 862 and Planetary Sciences, $33: 37-112$.

863 Shaked, Y., Avigad, D., Garfunkel, Z. 2000. Alpine high-pressure metamorphism at the 864 Almyropotamos window (southern Evia, Greece). Geological Magazine, 137 : 367-380.

865 Siyako, M., and Huvaz, O. 2007. Eocene stratigraphic evolution of the Thrace Basin, Turkey. 866 Sedimentary Geology, $198:$ 75-91.

867 Snel, E., Marunteanu, M., and Meulenkamp, J.E. 2006. Calcareous nannofossil 868 biostratigraphy and magnetostratigraphy of the Upper Miocene and Lower Pliocene of the 869 Northern Aegean (Orphanic Gulf-Strimon Basin areas), Greece. Palaeogeography, 870 Palaeoclimatology, Palaeoecology, 238 : 125 - 150, doi: 10.1016/j.palaeo.2006.03.022.

871 Sokoutis, D., Brun, J.-P., Van Den Driessche, J., and Pavlides, S. 1993. A major Oligo872 Miocene detachment in southern Rhodope controlling north Aegean extension. Journal of 873 the Geological Society, London, $150: 243-246$.

874 Sözbilir, H., Sarı, B., Uzel, B., Sümer, Ö., and Akkiraz, S. 2011. Tectonic implications of 875 transtensional supradetachment basin development in an extension-parallel transfer zone: 
876 the Kocaçay Basin, western Anatolia, Turkey. Basin Research, 23 : 423-448. 877 http://dx.doi.org/10.1111/j.1365-2117.2010.00496.x.

878 Taymaz, T., Jackson, J., McKenzie, D., 1991. Active tectonics of the north and central 879 Aegean Sea. Geophysical Journal International, 106 : 433-490.

880 Thomson, S.N., Stoeckhert, B., and Brix, M.R. 1998. Thermochronology of the high-pressure 881 metamorphic rocks of Crete, Greece; implications for the speed of tectonic processes. 882 Geology, $26: 259-262$.

883 Tirel, C., Gueydan, F., Tiberi, C., and Brun, J.-P. 2004. Aegean crustal thickness inferred 884 from gravity inversion. Geodynamical implications. Earth and Planetary Science Letters, $885 \quad 228: 267-280$.

886 Tirel, C., Brun, J.-P., and Sokoutis, D. 2006. Extension of thickened and hot lithospheres: 887 Inferences from laboratory modeling. Tectonics, 25: TC1005, doi:10.1029/2005TC001804 888 Tirel, C., Brun, J.-P., and Burov, E. 2008. Dynamics and structural development of 889 metamorphic core complexes. Journal of Geophysical Research, 113 : B04403, 890 doi:10.1029/2005JB003694

891 Tirel, C., Brun, J.-P., Burov, E., Wortel, M., and Lebedev, S. 2013. A plate tectonics oddity: 892 Caterpillar-walk exhumation of subducted continental crust. Geology, 41 : 555-558.

893 Urai, V.L., Shuiling, R.D., and Jansen, J.B.H. 1990. Alpine deformation on Naxos (Greece). 894 In: Knipe, R.J., Rutter, E.H. (Eds.), Deformation Mechanisms, Rheology and Tectonics 895 Geological Society, Special Publications, $54: 509-522$.

896 Uzel, B, Sözbilir, H., Özkaymak, C, Kaymakc1, N., and Langereis, C.G. 2013. Structural 897 evidence for strike-slip deformation in the İzmir-Balikesir transfer zone and consequences 898 for late Cenozoic evolution of western Anatolia (Turkey). Journal of Geodynamics, 65 : $89994-116$. 
900 Uzel, B., Langereis, C.G., Kaymakci, N., Sözbilir, H., Özkaymak, Ç., and Özkaptan, M. 2015.

901 Paleomagnetic evidence for an inverse rotation history of Western Anatolia during the 902 exhumation of Menderes core complex. Earth and Planetary Science Letters, 414 : 108$903 \quad 125$.

904 van Hinsbergen, D.J.J., 2010. A key extensional metamorphic complex reviewed and 905 restored: The Menderes Massif of western Turkey. Earth Sciences Review, 102 : 60-76, 906 doi:10.1016/j.earscirev.2010.05.005.

907 van Hinsbergen, D.J.J., and Schmid, S.M. 2012. Map view restoration of Aegean-West 908 Anatolian accretion and extension since the Eocene. Tectonics, 31 : TC5005, 909 doi:10.1029/2012TC003132.

910 van Hinsbergen, D.J.J., Langereis, C.G., and Meulenkamp, J.E. 2005. Revision of the timing, 911 magnitude and distribution of Neogene rotations in the western Aegean region. 912 Tectonophysics, $396: 1$-34. doi: 10.1016/j.tecto.2004.10.001.

913 van Hinsbergen, D.J.J., Dekkers, M. J., Bozkurt, E. and Koopman, M., 2010. Exhumation

914 with a twist: Paleomagnetic constraints on the evolution of the Menderes metamorphic

915 core complex, western Turkey. Tectonics, 29, TC3009, doi:10.1029/2009TC002596.

916 Wawrzenitz, N., and Krohe, A. 1998. Exhumation and doming of the Thasos metamorphic 917 core complex (S Rhodope, Greece): structural and geochronological constraints. $918 \quad$ Tectonophysics, $285: 301-332$.

919 Weidmann, M., Solounias, N., Drake, R.E., and Curtis, G.H., 1984. Neogene stratigraphy of 920 the eastern basin, Samos Island, Greece. Geobios, $17: 477-490$.

921 Widiyantoro, S., van der Hilst, R.D., and Wenzel F. 2004. Deformation of the Aegean Slab 922 in the Mantle Transition Zone. International Journal of Tomography \& Statistics, D04 :1923 14. December 2004 ISSN 0972-9976;

924 Wortel, M.J.R., and Spakman, W. 2000. Subduction and slab detachment in the 
925 Mediterranean-Carpathian region. Science, $290: 1910-1917$.

926 Wuthrich, E. 2009. Low temperature thermochronology of the North Aegean Rhodope

927 Massif, Ph.D. thesis, Swiss Federal Institute of Technology, Zurich.

928 
929

930

931 Fig. 1. Simplified geological map of the Aegean domain in Tertiary showing the three main 932

933

934

935

936

937

938

939

940

941

942

943

944

945

946

947

948

949

950

951

952

953

\section{Figure captions}

continental blocks, Rhodopia, Pelagonia and Adria, separated by the Vardar and Pindos suture zones. The cross-section shows the present-day crustal-scale structure of the Aegean domain and the geometry of the Hellenic subduction. NAF: North Anatolian Fault. NAT: North Aegean Through. MIF: Myrthes-Ikaria Fault.

Fig. 2. Distribution of Paleogene (a) and Neogene (b) basins in the Aegean domain. Acronyms same as in Figure 1.

Fig. 3. The two core complexes (High-temperature metamorphism) of the Aegean domain. SRCC: Southern Rhodope Core Complex, which exhumed between $45 \mathrm{Ma}$ and $18 \mathrm{Ma}$ and whose detachment dip southwestward. CCCC: Central Cyclades Core Complex, whose exhumation history is shown by a PTt diagram from Naxos (Numbers in circles: Time in My) (After Duchêne et al. 2006 in Jolivet and Brun 2010) and whose detachment dip northeastward to the West and Northward to the East. Red arrows: syn-metamorphic senses of shear. Senses of shear associated to core complex extension after Sokoutis et al (1993) and Brun and Sokoutis (2007) for the SRCC and Gautier et al (1993) and Gautier and Brun (1994) for the CCCC.

Fig. 4. High-pressure metamorphism in the Adria and Pelagonia blocks. PTt diagrams illustrate the exhumation history of the Cycladic Blueschist Unit in Tinos (Numbers in circles: Time in My) (After Parra et al. 2002 in Jolivet and Brun 2010) and of the " Phyllite-Quartzite Nappe » in Peloponnese (Numbers in circles: Time in My) (After Jolivet et al. 2010a). Black 
954 arrows: sense of shear related to subduction. White arrows: sense of shear related to 955 exhumation. Senses of shear associated to subduction (black arrows) after Huet et al (2009) 956 and Philippon et al (2012). Senses of shear associated to exhumation (white arrows) after 957 Gautier and Brun (1994) for the Cyclades and Jolivet et al (2010a) for the Peloponnese and 958 Crete.

959

960 Fig. 5. Frequency distribution histograms of low-temperature thermochronology ages (apatite 961 and zircon fission tracks (AFT and ZFT) and UTh/He on apatite and zircon) in Rhodope (data 962 from Wuthrich 2009), Cyclades (Compilation of data: Philippon et al. 2012) and 963 Peloponnese-Western Crete (data from Brix et al. 2002; Marsellos et al. 2014). Numbers 964 correspond to the number of ages within a bin.

965

966 Fig. 6. Major strike-slip faults and sedimentary basins in the Aegean Sea, as displayed by 967 bathymetry (GMRT bathymetry data from Carbotte et al. 2004). The Myrthes-Ikaria fault that 968 connects the Myrthes and Ikaria basins (Philippon et al. 2012, 2014) is the offshore extend of 969 the onshore Izmir-Balikeshir Transfer Zone (Sozbilir et al. 2010), located between the Izmir970 Ankara suture zone and the Menderes Massif (pink).

971

972 Fig. 7. Present-day displacements (after Nyst and Thatcher 2004) superposed to the map of

973 Neogene basins (Yellow) showing that a major change occurred in the course of post-Middle

974 Miocene deformation when the North Anatolian Fault (NAF) localized and connected to the 975 North Aegean Through (NAT).

976

977 Fig. 8. Change in the principal direction of stretching between Pliocene to Lower (?) 978 Pleistocene (a) and Lower (?) Pleistocene to Present (b) related to the localization of the 
979 North Anatolian Fault in the North Aegean (Principal directions of stretching after Lyberis 980 1984; Bathymetry data GMRT from Carbotte et al. 2004).

981

982 Fig. 9. Restoration of Aegean extension in map view at 5, 15, 30 and 45 Ma. Colours of 983 continental blocks and suture zones same as in Figure 1. Orange: Paleogene basins (MHT: 984 Mid Hellenic Trough; XB: Xanthi Basin; TB: Thrace Basin). Yellow: Neogene basins; only 985 shown in the present-day map (e). Red and white arrows (in b to e): principal direction of 986 stretching and sense of shear related to exhumation of high-temperature (core complexes) and 987 high-pressure metamorphic rocks, respectively (See Figs. 3 and 4). Black arrows (in a): 988 principal direction of stretching and sense of shear related to subduction of Adria, in their 989 position at the onset of extension at $45 \mathrm{Ma}$. Top-to-SW shear in the SRCC (Red arrows in b to 990 e) and top-to-NE shear in blueschists (White arrows in b to e) started to develop at $45 \mathrm{Ma}$. 991 Top-to-NE shear in the CCCC (Red arrows in c to e) started to develop prior to 20.7 Ma. All 992 arrows, except the black ones, are represented at all stages following their initial development 993 as their final position reflect block rotations.

994

995 Fig. 10. Restoration of Aegean extension along two NE-SW trending lithosphere-scale cross996 sections $\mathrm{AA}^{\prime}$ and $\mathrm{BB}^{\prime}$ (see location on map). Shape of the Hellenic slab (in sections) and 997 geometry of the slab tear (map view) from the S-wave tomographic model of Salaün (2011). 998 The slab tear of section AA' passes to a fold in section BB' (See slab tear contours in red on 999 map). At $45 \mathrm{Ma}$, the restoration shows the geometry of the thrust wedge resulting from the 1000 pilling up of Rhodopia (Brown), Pelagonia (Purple) and Adria (Blue) continental blocks 1001 separated by the suture zones of the Vardar (Green) and the Pindos (Orange). Extension that 1002 is a direct function of the amount of trench retreat is much larger in section $\mathrm{AA}^{\prime}$ than in 1003 section BB' where it is mostly located to the North of the Vardar suture zone. 
1004

1005 Fig. 11. Rate of trench retreat along section AA' (Fig.10) showing an acceleration by a factor 10065 since Middle Miocene, from 0.6 to $3.2 \mathrm{~cm} \mathrm{y}^{-1}$, that correlates i) with a change in the mode 1007 of extension from localized/stage 1 (exhumation of HT and HP metamorphic rocks) to 1008 distributed/stage 2 (segmentation of exhumed metamorphic units and deposition of Neogene 1009 basins over the whole Aegean domain) and ii) with the strong contrast in shape and 1010 distribution of Paleogene and Neogene basins (Fig. 2). 

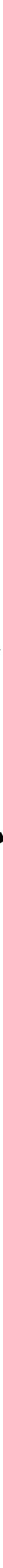

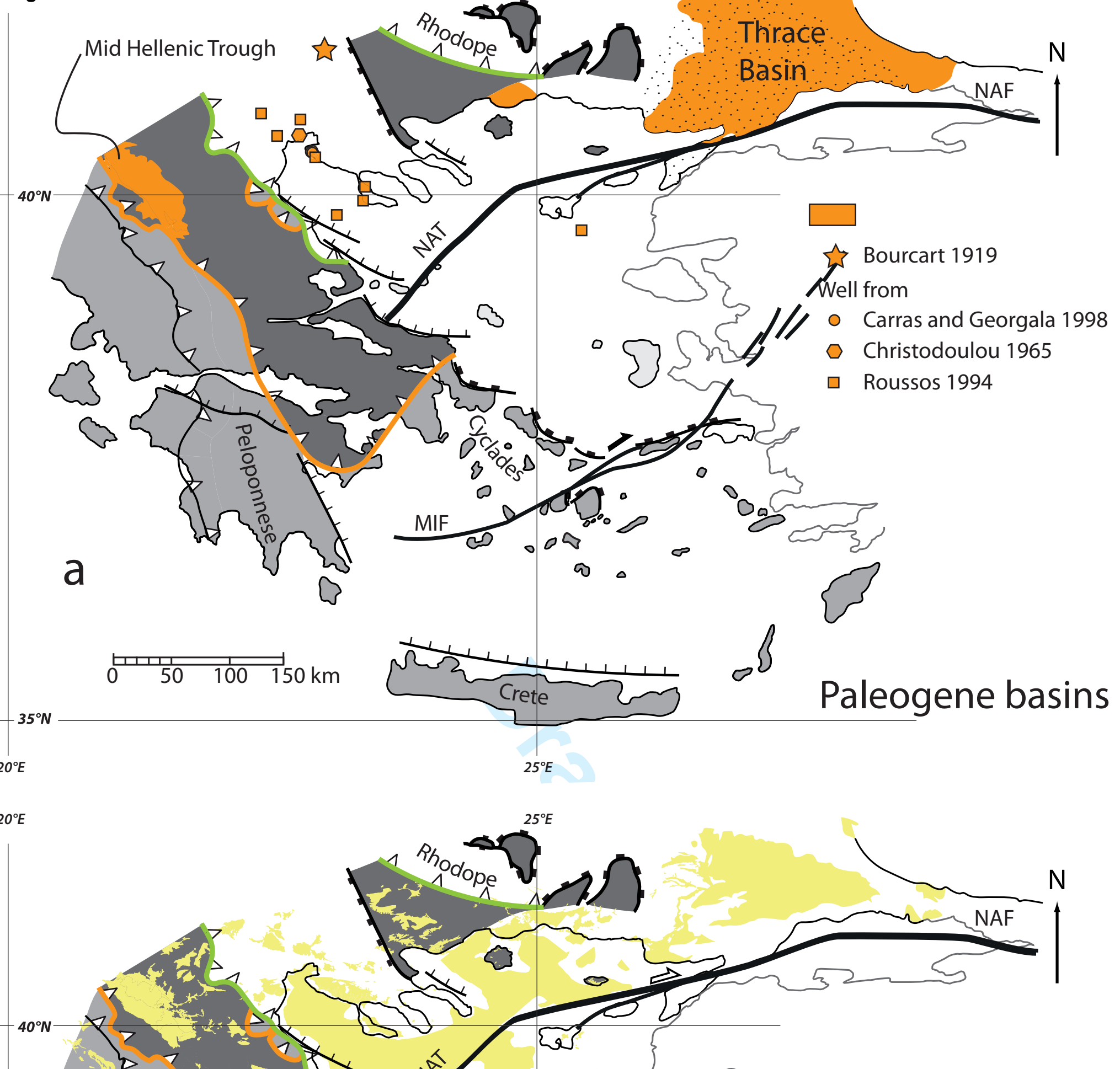

b 


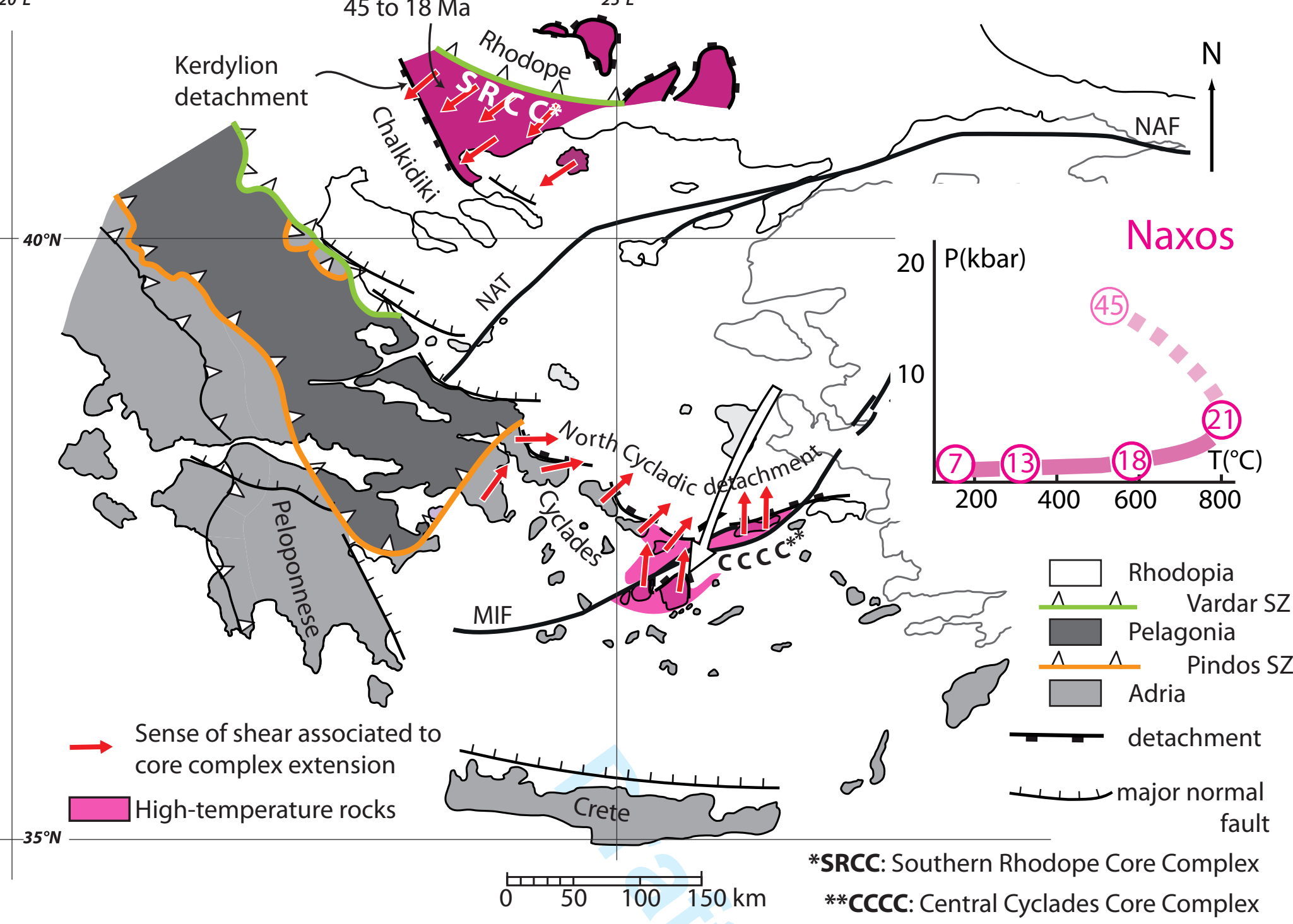




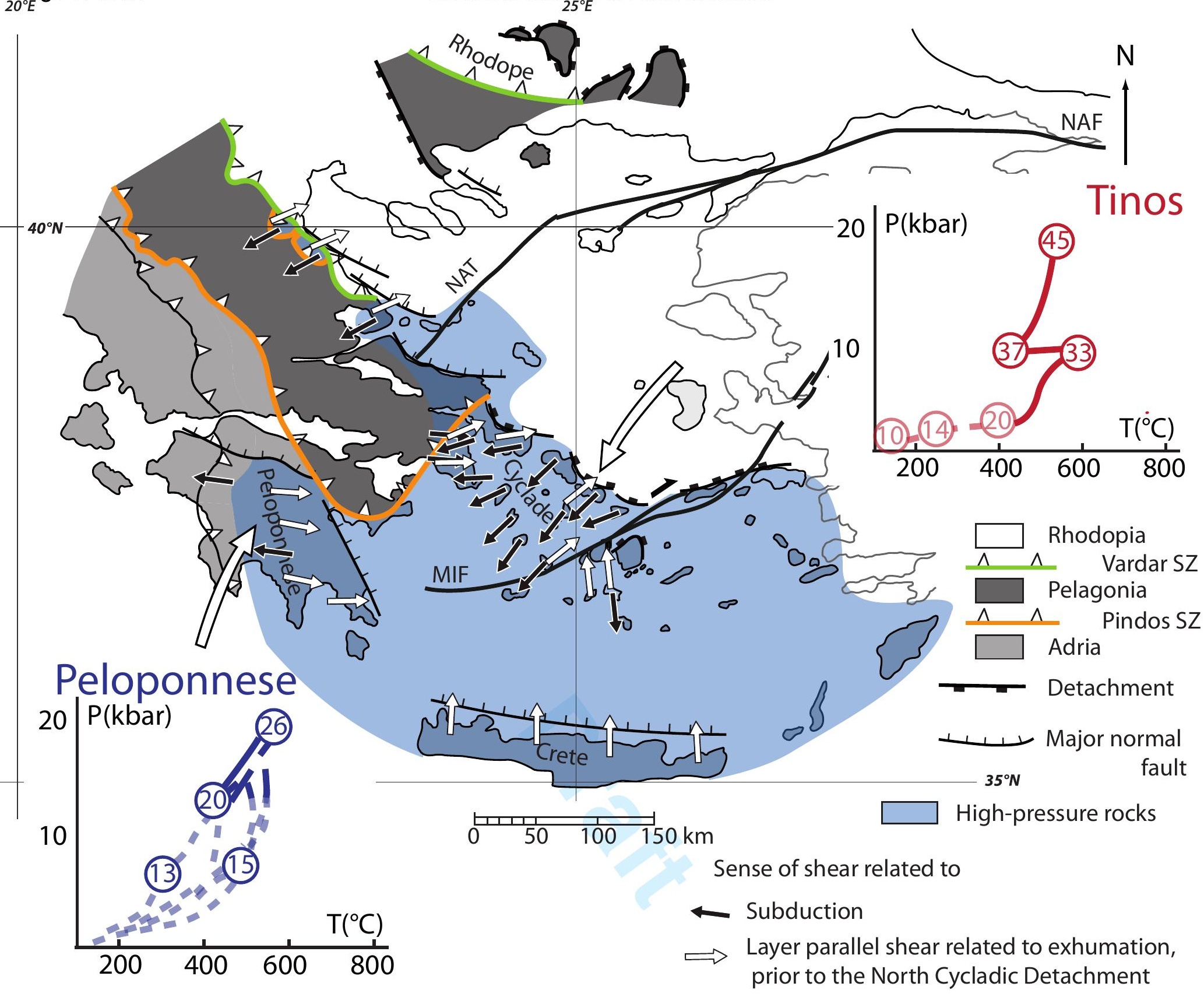



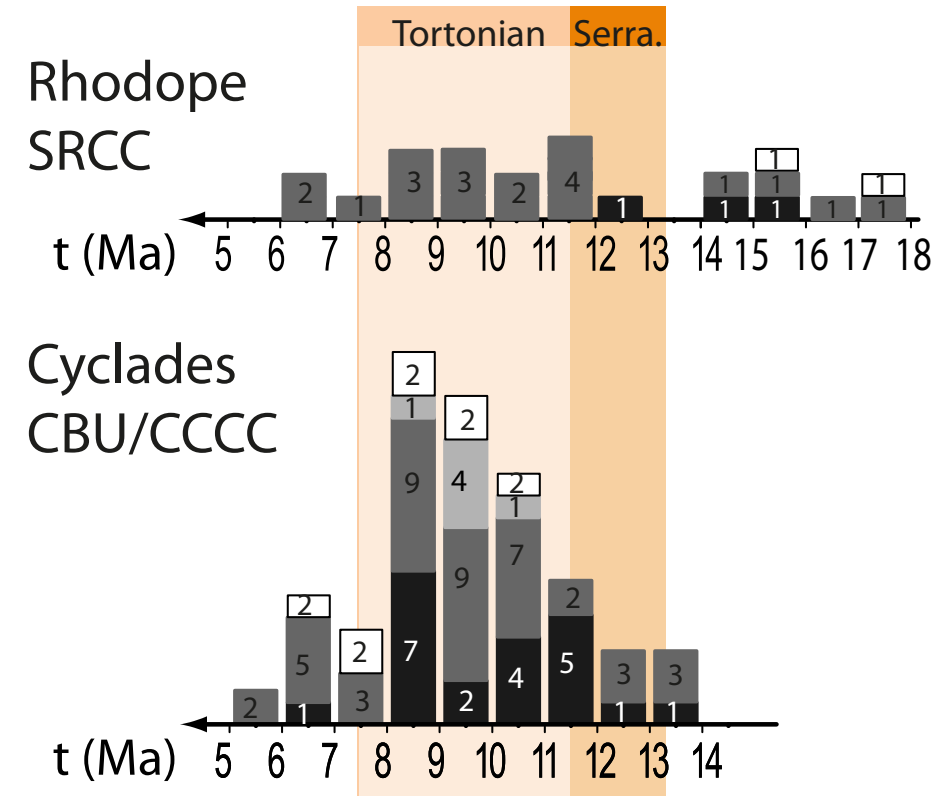

\section{Crete}

Peloponnese

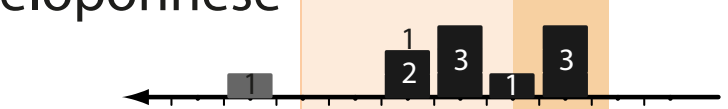

$\mathrm{t}(\mathrm{Ma}) \quad \begin{array}{llllllllll}5 & 6 & 7 & 8 & 9 & 10 & 11 & 12 & 13 & 14\end{array}$

$\square$ U,Th/He Apatite $\quad$ AFT
U,Th/He Zircon $\quad$ ZFT




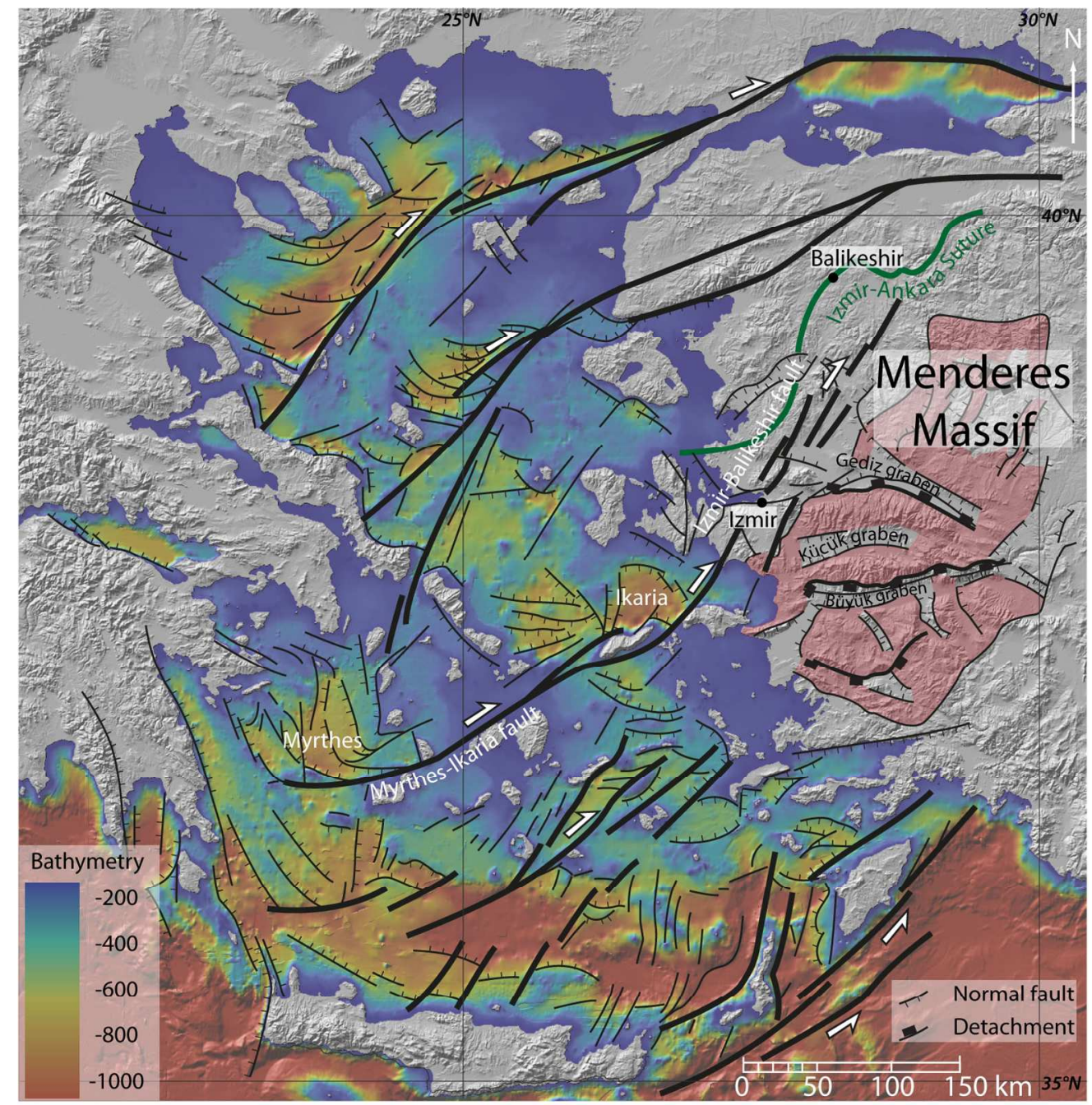

Major strike-slip faults and sedimentary basins in the Aegean Sea, as displayed by bathymetry (GMRT bathymetry data from Carbotte et al. 2004). The Myrthes-Ikaria fault that connects the Myrthes and Ikaria basins (Philippon et al. 2012, 2014) is the offshore extend of the onshore Izmir-Balikeshir Transfer Zone (Sozbilir et al. 2010), located between the Izmir-Ankara suture zone and the Menderes Massif (pink). $418 \times 429 \mathrm{~mm}(100 \times 100 \mathrm{DPI})$ 

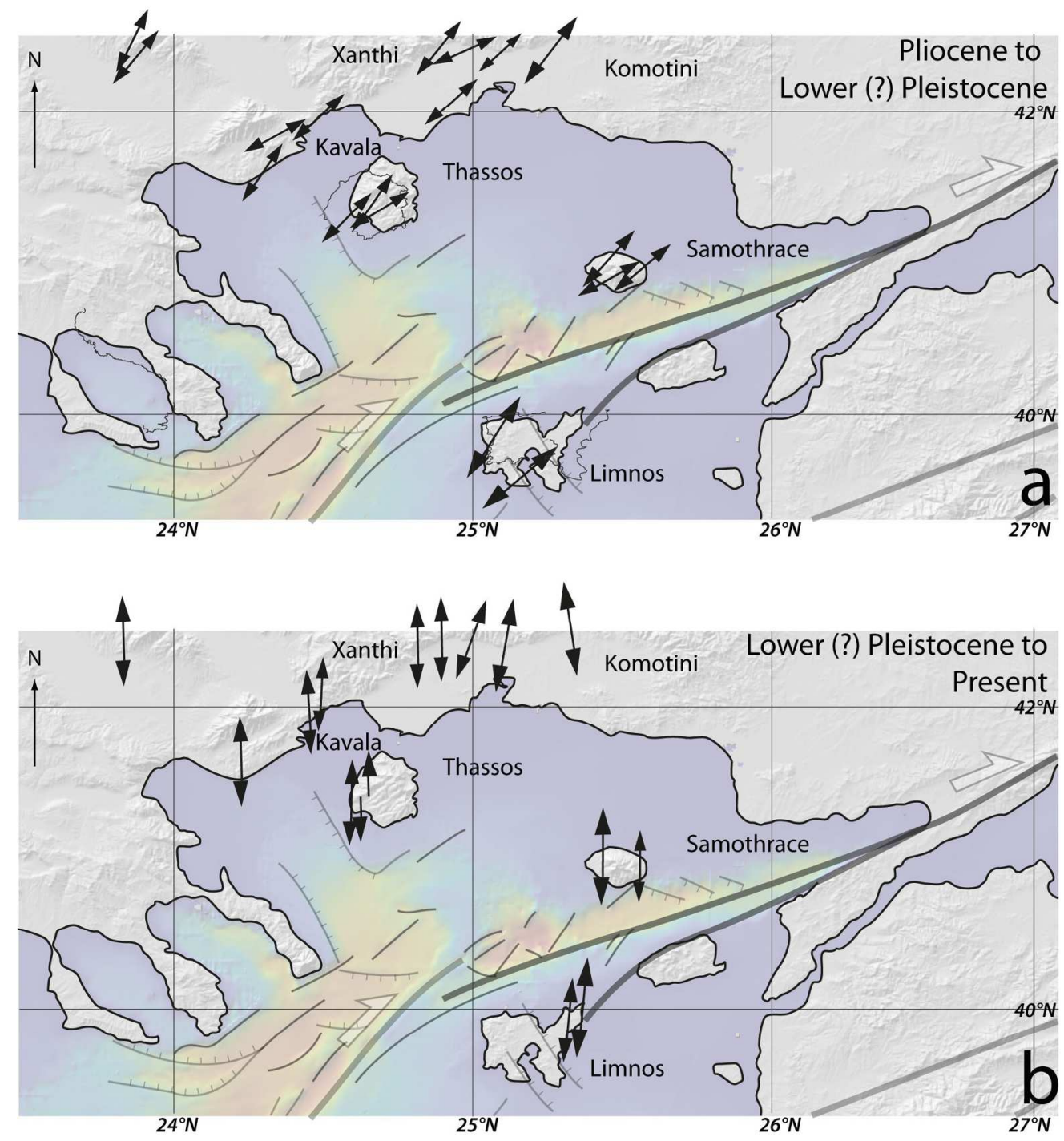

Change in the principal direction of stretching between Pliocene to Lower (?) Pleistocene (a) and Lower (?) Pleistocene to Present (b) related to the localization of the North Anatolian Fault in the North Aegean (Principal directions of stretching after Lyberis 1984; Bathymetry data GMRT from Carbotte et al. 2004). $716 \times 774 \mathrm{~mm}(72 \times 72 \mathrm{DPI})$ 
$\otimes$

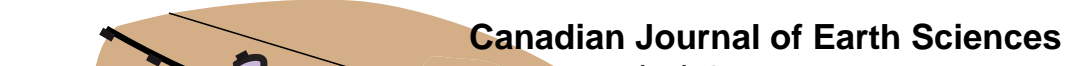

$\otimes$

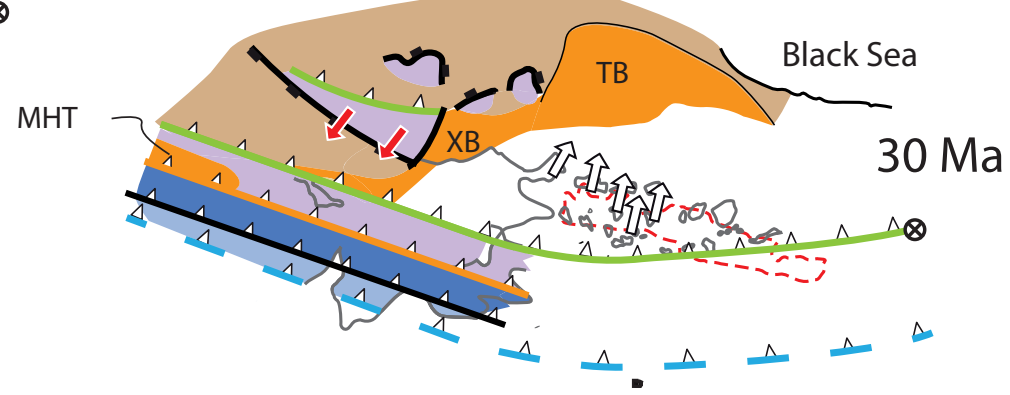

$\otimes$

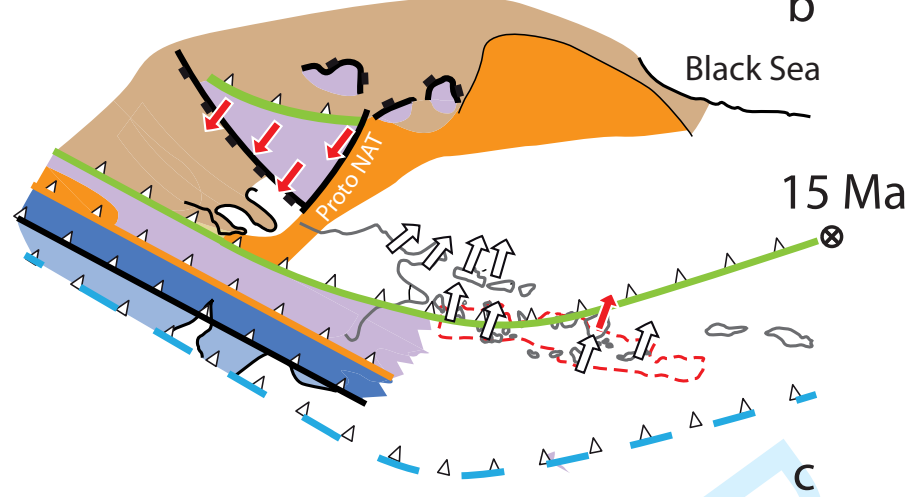

$\otimes$

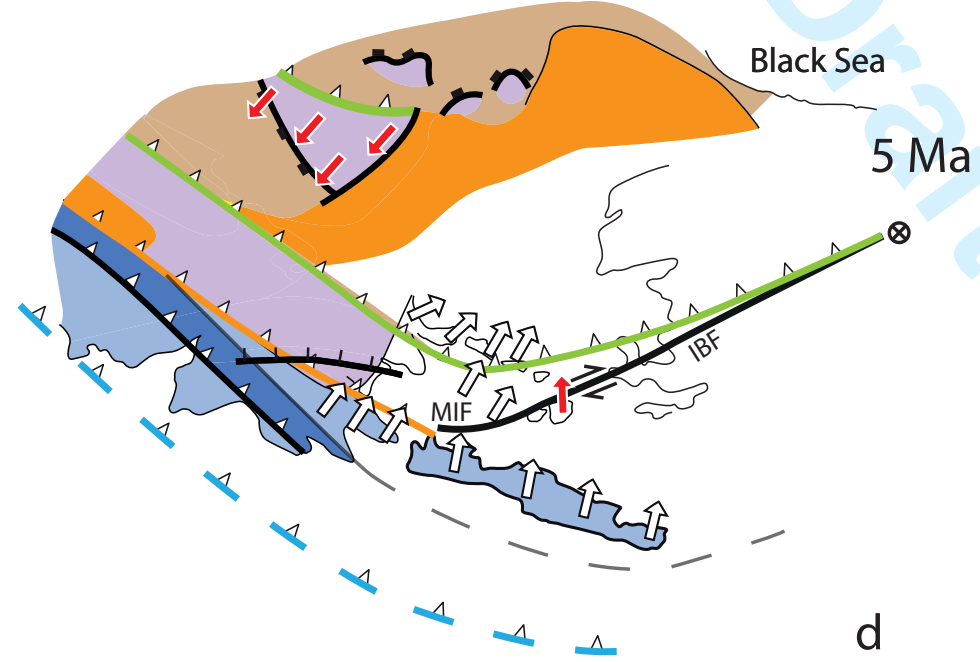

$\otimes$

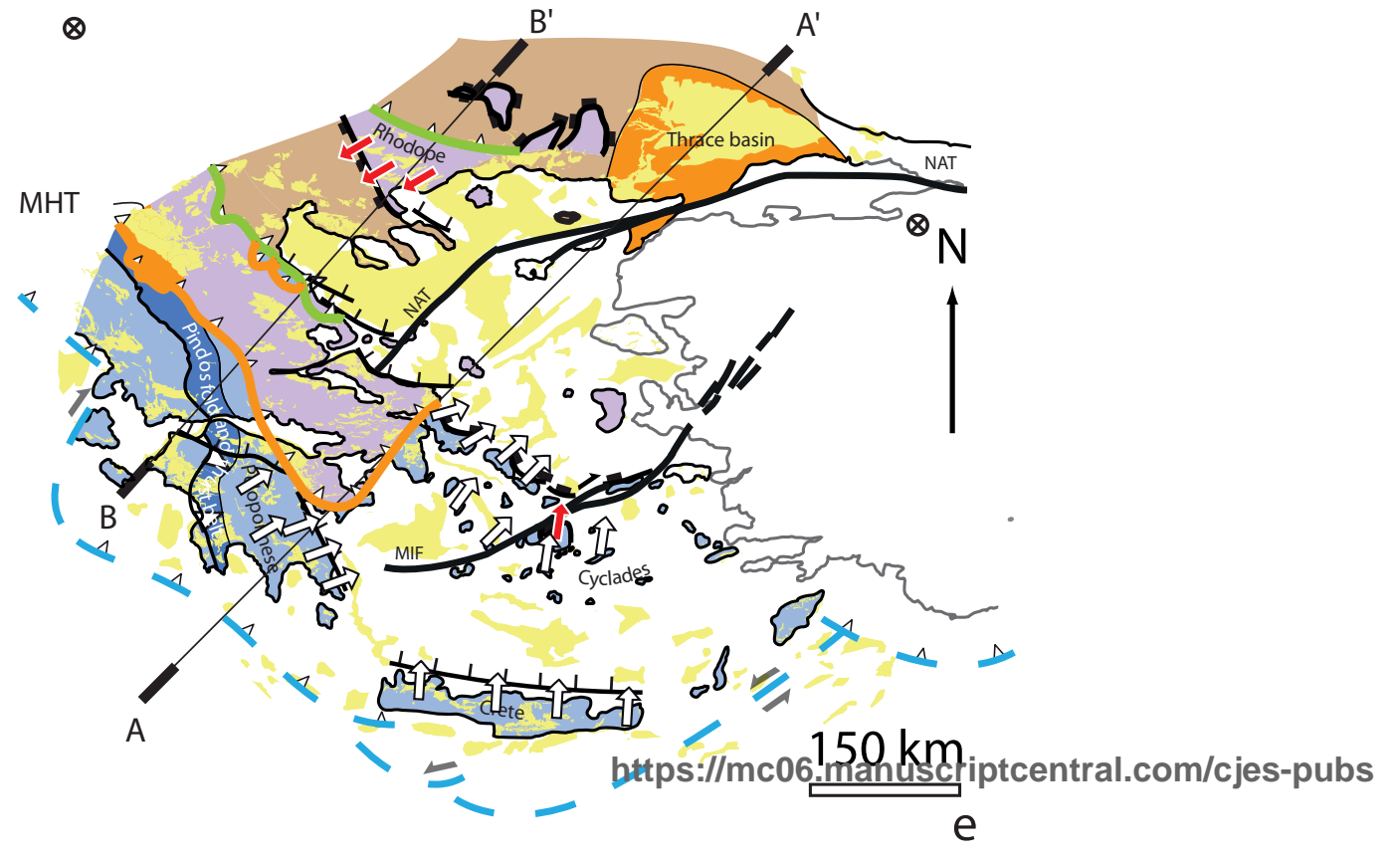


Pindos

fold \& thrust

belt
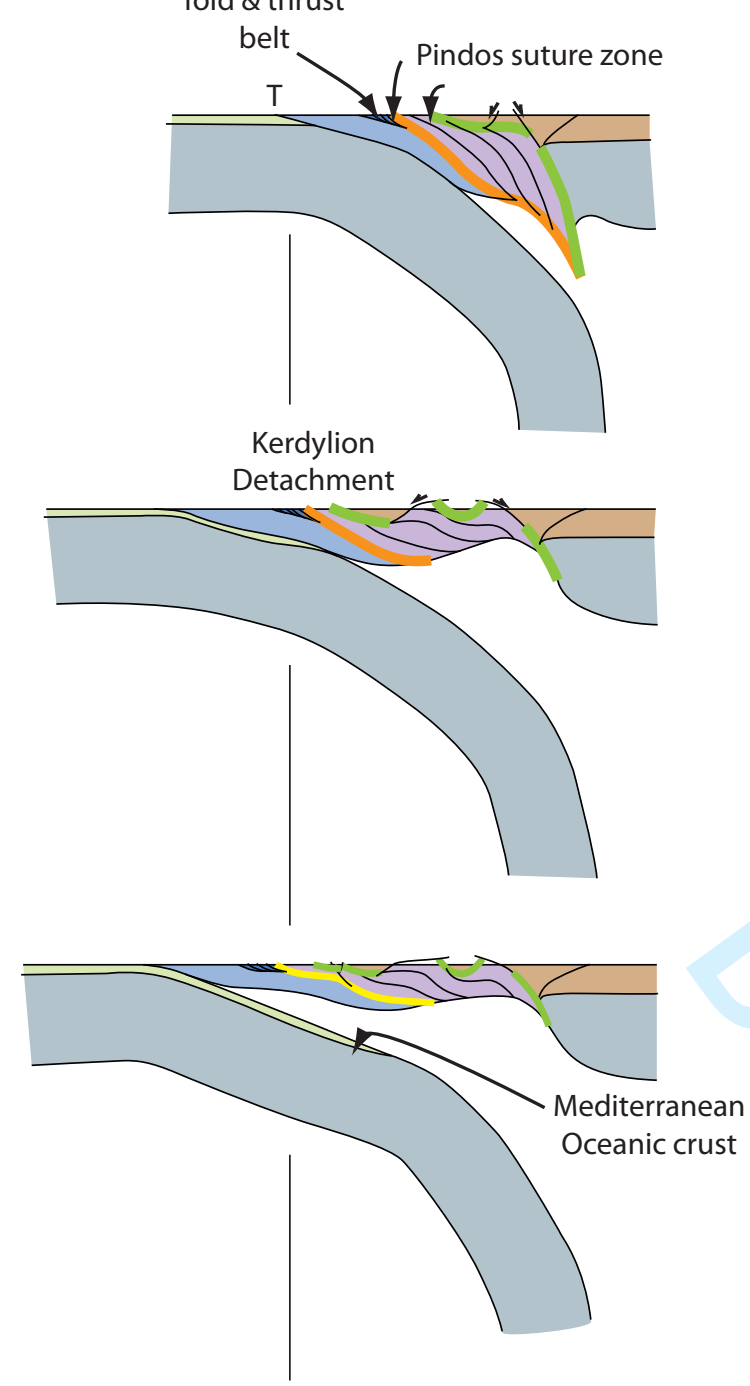

$15 \mathrm{Ma}$

$30 \mathrm{Ma}$

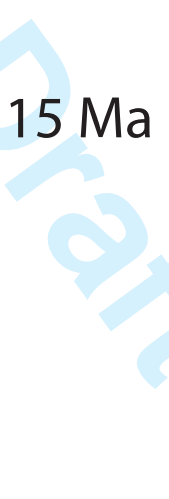

$5 \mathrm{Ma}$
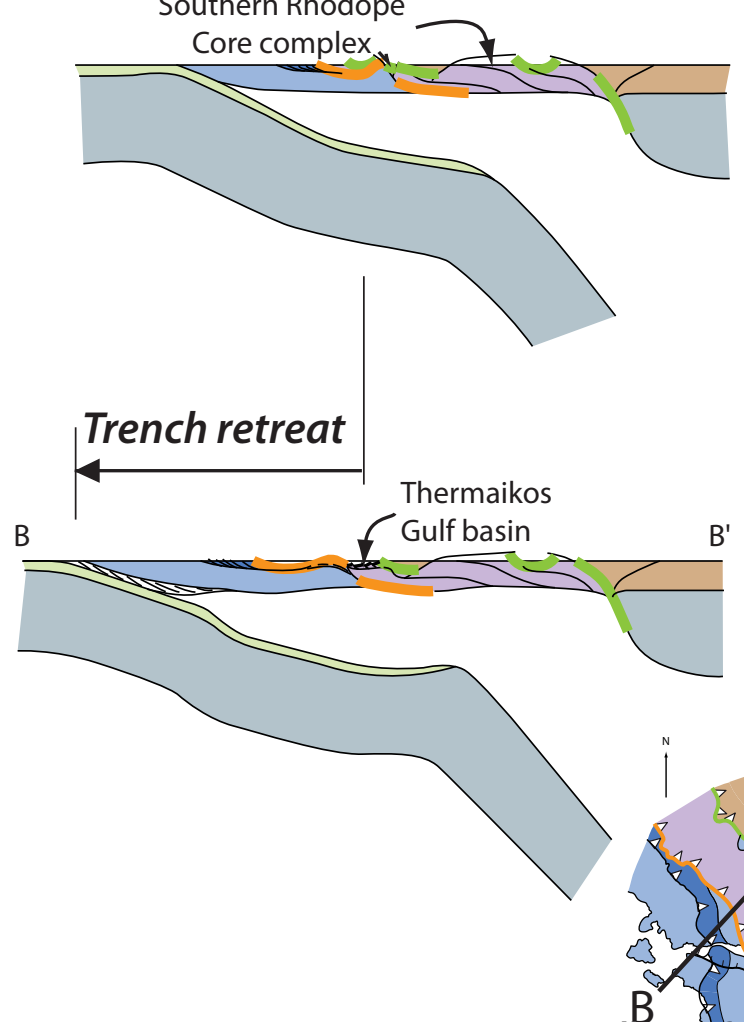

Present day

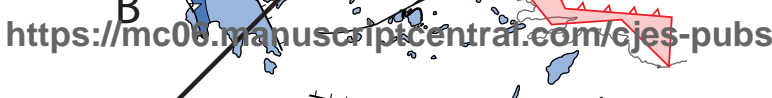
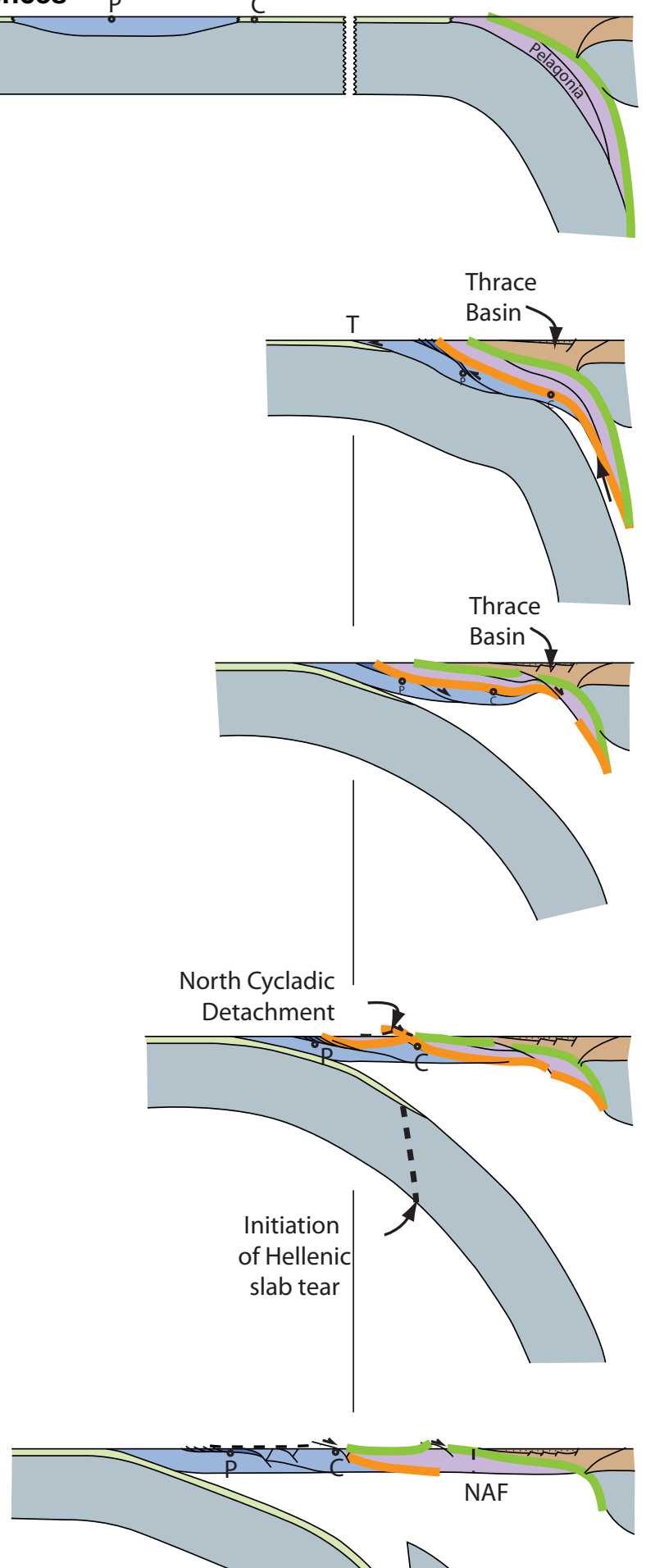

orth

Anatolian Fault
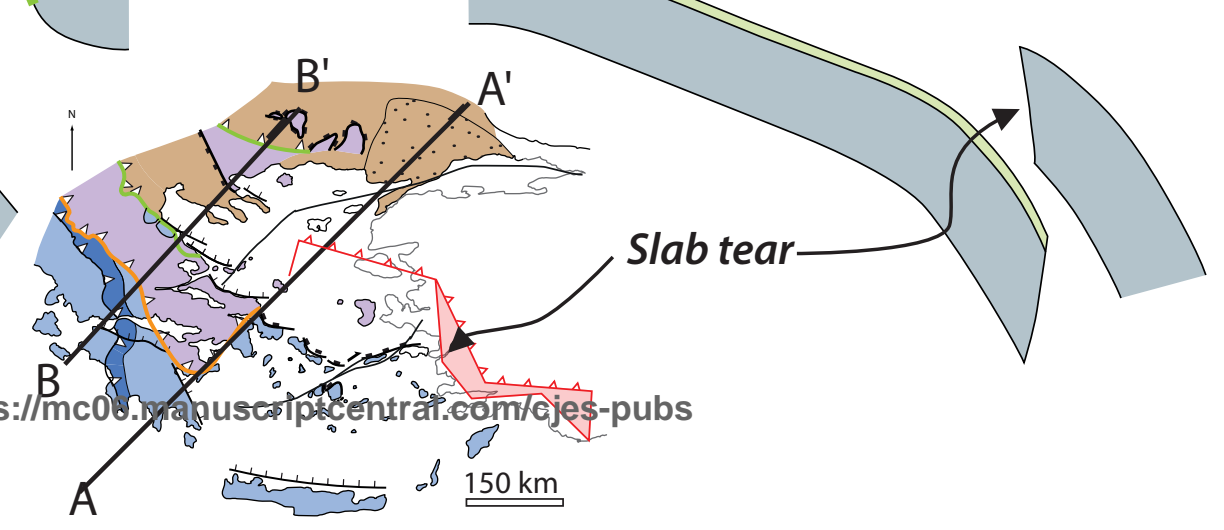


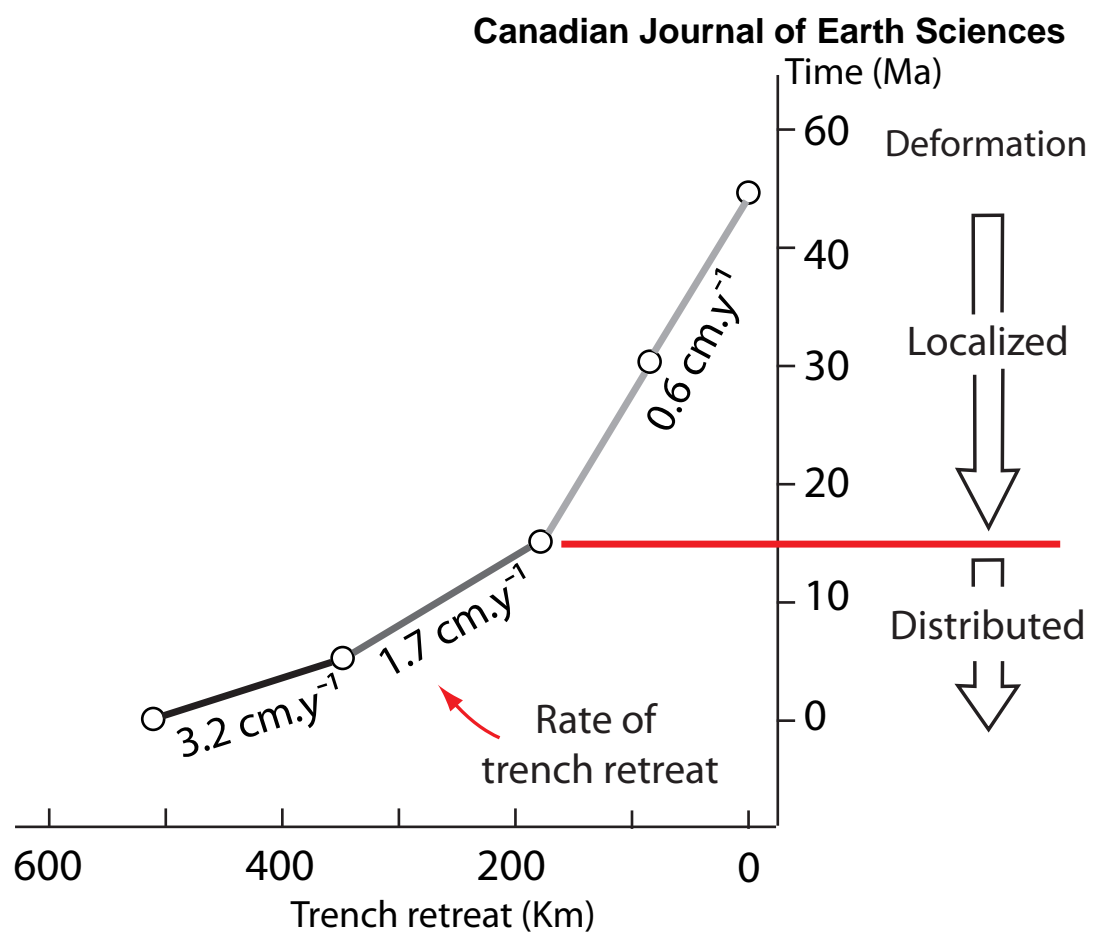

Main tectonic event

Exhumation of HT \& HP metamorphic rocks

Segmentation of HT \& HP metamorphic units in transtension Paleogene

Basins

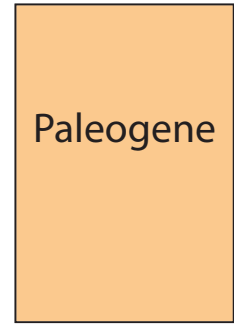

Neogene 